\title{
Plankton community structure and carbon cycling in a coastal upwelling system. II. Microheterotrophic pathway
}

\author{
Cristian A. Vargas ${ }^{1, *}$, Humberto E. González ${ }^{2}$ \\ ${ }^{1}$ Department of Oceanography, Universidad de Concepcion, Casilla 160-C, Concepcion, Chile \\ ${ }^{2}$ Institute of Marine Biology ‘Dr. Jürgen Winter', Universidad Austral de Chile, Casilla 567, Valdivia, Chile
}

\begin{abstract}
Planktonic food-web structure and carbon dynamics were studied in Mejillones Bay $\left(23^{\circ} \mathrm{S}\right.$, off northern Chile) on 3 occasions: February, August and October 2001. Mejillones Bay was influenced by moderate upwelling events during February and October and presented a shallow (30 to $40 \mathrm{~m}$ depth) oxygen minimum layer (OML). On all sampling occasions, chain-forming diatoms that were grazed by small zooplankton and heterotrophic (h-)dinoflagellates comprised most of the autotrophic biomass. Heterotrophic (h-)nanoflagellates were largely bacterivorous, and responsible for a substantial removal of bacterial biomass, mostly associated with productive surface waters and the OML. Ciliate biomass was relatively low during all periods, but ciliates removed a large fraction of h-nanoflagellate production (12 to $22 \% \mathrm{~d}^{-1}$ ). Thus, in the microbial food web bacterial carbon can be transferred to ciliates and then subsequently to zooplankton. The impact of small zooplankton on primary production (PP) was relatively low on all sampling occasions. Small copepods and appendicularians removed from 0.6 to $5 \%$, and from 0.08 to $0.6 \% \mathrm{PP} \mathrm{d}^{-1}$ respectively. Appendicularians were the only zooplankton able to graze on bacteria, but grazing impact was not sufficient to regulate bacterial biomass. The microheterotrophic pathway could be an important link in this highly productive upwelling embayment. Our results showed that a large part of the photosynthetically fixed carbon was channeled through the microbial food web, with only a small part allocated to copepods and appendicularians. The food-web structure of Mejillones Bay can be classified as multivorous, with herbivorous and microbial grazing playing an important role in carbon export.
\end{abstract}

KEY WORDS: Microbial food web · Protozoans · Upwelling system · Copepods · Appendicularians · Carbon flow $\cdot$ Humboldt Current System

\section{INTRODUCTION}

In the past, our understanding of coastal upwelling systems was strongly influenced by classical studies (e.g. Ryther 1969) which, when estimating fish production, assumed that there were few trophic levels and a high trophic efficiency in upwelling regions. Even now, the importance of the microbial food web to the food webs of fishes is commonly disregarded by fisheries scientists (e.g. Boudreau \& Dickie 1992, Cury et al. 2000). Carbon fixed by primary producers is transferred along upwelling food webs through both 'microbial' and 'classical' pathways, and the proportion di- rected along each route probably depends largely on the size of the primary producers (Walker \& Peterson 1991, Mann 1992). There is increasing evidence that the microbial food web is a fundamental and almost permanent feature of not only oligotrophic but also eutrophic marine systems (Neuer \& Cowles 1994, Tamigneaux et al. 1997). The significance of bacteria and microprotozoans as components of the biomass, and their role in biogeochemical cycles in upwelling systems have been widely recognized (Newel \& Turley 1987, Painting et al. 1992, Ducklow et al. 2001). Previous studies in upwelling regions along the west coast of North America (Heinbockel 1978, Landry \& Hassett 
1982, Landry \& Lorenzen 1989); and off Peru (Beers et al. 1971, Sorokin 1978) have shown that protists can be an important component of the plankton community. However, trophic relationships within the microbialloop food web in upwelling systems are poorly understood and greatly simplified (Painting et al. 1992). Because of the high production of upwelling regions and their importance for carbon fluxes from continental shelves to slopes (Walsh et al. 1981), more knowledge on the magnitude and variability of protist activity in upwelling regions is needed.

Like the rest of the northern part of the Humboldt Current System (HCS), the nearshore environment off northern Chile is influenced by intermittent upwelling events and it is also one of the most biologically productive areas within the HCS. Although new data on primary production in this region has been reported (Daneri et al. 2000), there is little data on the fate of this production in either the microheterotrophic or zooplankton pathways. Carbon fluxes through the pelagic food web off northern Chile are poorly known. In a multidisciplinary study in northern Chile off Antofagasta before and during the development of an El Niño event, González et al. (1998), suggested that zooplankton could remove from 4 to $6 \%$ of primary production (PP). However, most research in the HCS has only studied zooplankton herbivory as the main pathway by which carbon is exported from the food web. In addition, carbon flow dynamics, especially those referring to the microbial loop, is still lacking, and it is therefore not known how much of the PP channeled through the microbial and classical food webs is available to higher trophic levels, including large fish populations. While large copepods such as Calanus spp. and Eucalanus spp. represent a major fraction of the biomass in offshore waters (e.g. Escribano \& Hidalgo 2000), the dominant small copepods (e.g. Paracalanus parvus, Acartia tonsa and Oithona similis) and appendicularians (Oikopleura spp.) are important components in nearshore waters and embayments along the HCS (Grünewald et al. 1998, González et al. 2000, Aravena \& Palma 2002). Small calanoid and cyclopoid copepods and appendicularians are known to be largely omnivorous and bacterivorous respectively (e.g. Tiselius 1989, Dagg et al. 1996, Vargas et al. 2002, Zeldis et al. 2002, Vargas \& González 2003, this issue). Therefore, when small zooplankton species feed on protozoans (which in turn feed effi- ciently on pico- and nanoplankton), the energy transfer from the microbial loop (including bacteria and protists), and also from the microbial food web (including autotrophic pico- and nanoplankton) to higher trophic levels may be greater than previously assumed.

The main objectives of the present study were to quantify the total grazing impact on PP by measuring and describing the trophic activity of various components of the planktonic food web in surface waters, and to determine the percentage of PP that could be channeled by the microprotozoan and small zooplankton pathways in an embayment off northern Chile. We estimated potential carbon fluxes and analyzed the interaction between the microheterotrophic food web and higher trophic levels on 3 occasions representing periods of different productivity and zooplankton community structure in order to assess the trophic interactions of different plankton groups.

\section{MATERIALS AND METHODS}

The investigation was conducted along a transect of 4 stations representing bay (Stn 1), shelf (Stns 2 and 3) and slope (Stn 4) conditions in Mejillones Bay, northern Chile (23 $\left.\mathrm{S}, 73^{\circ} 20^{\prime} \mathrm{W}\right)$ (Fig. 1). Sampling was performed on board the RV 'Purihaalar' (Universidad de Antofagasta) on 3 occasions: 10 to 14 February, 1 to 5 August and 20 to 25 October 2001; on each occasion, the stations were sampled twice (i.e. 2 legs).

Hydrography. Temperature, salinity and oxygen profiles were recorded from near the bottom to the sur-

Table 1. Spatial-temporal oceanographic and biological data for 3 cruises: 10 to 14 February, 1 to 5 August and 20 to 25 October 2001. Each cruise sampled 4 stations, with 2 legs per cruise. N: no of measurements at each station

\begin{tabular}{|c|c|c|c|}
\hline Measurement & Depths & $\mathrm{N}$ & Instruments \\
\hline $\begin{array}{l}\text { Temperature } \\
\text { Salinity } \\
\text { Oxygen } \\
\text { Fluorescence }\end{array}$ & Profiles & 3 profiles & $\begin{array}{l}\text { SeaBird SBE-19 } \\
\text { CTD with Beckman } \\
\text { oxygen sensor }\end{array}$ \\
\hline Light extinction & & $\sim 3$ & Secchi Disk \\
\hline Chlorophyll a & $\begin{array}{c}1,5,10,25,50 \\
\text { and } 100 \mathrm{~m}\end{array}$ & 2 profiles & 301 Niskin bottles \\
\hline Bacterial biomass & $1,25,50 \mathrm{~m}$ & $\begin{array}{l}3 \text { samples } \\
\text { per depth }\end{array}$ & 301 Niskin bottles \\
\hline Protozoan biomass & $1,25,50 \mathrm{~m}$ & $\begin{array}{l}3 \text { samples } \\
\text { per depth }\end{array}$ & 301 Niskin bottles \\
\hline Phytoplankton biomass & $1,25,50 \mathrm{~m}$ & $\begin{array}{l}3 \text { samples } \\
\text { per depth }\end{array}$ & 301 Niskin bottles \\
\hline \multirow[t]{2}{*}{ Zooplankton biomass } & $\begin{array}{c}4 \text { strata: } \\
0-25 ; 25-50 ; \\
50-100 \text { and } \\
100-150 \mathrm{~m}\end{array}$ & $\begin{array}{l}3 \text { WP-2 } \\
\text { plankton } \\
\text { tows }\end{array}$ & WP-2 net \\
\hline & Integrated & 1 Bongo net tow & Bongo net \\
\hline
\end{tabular}




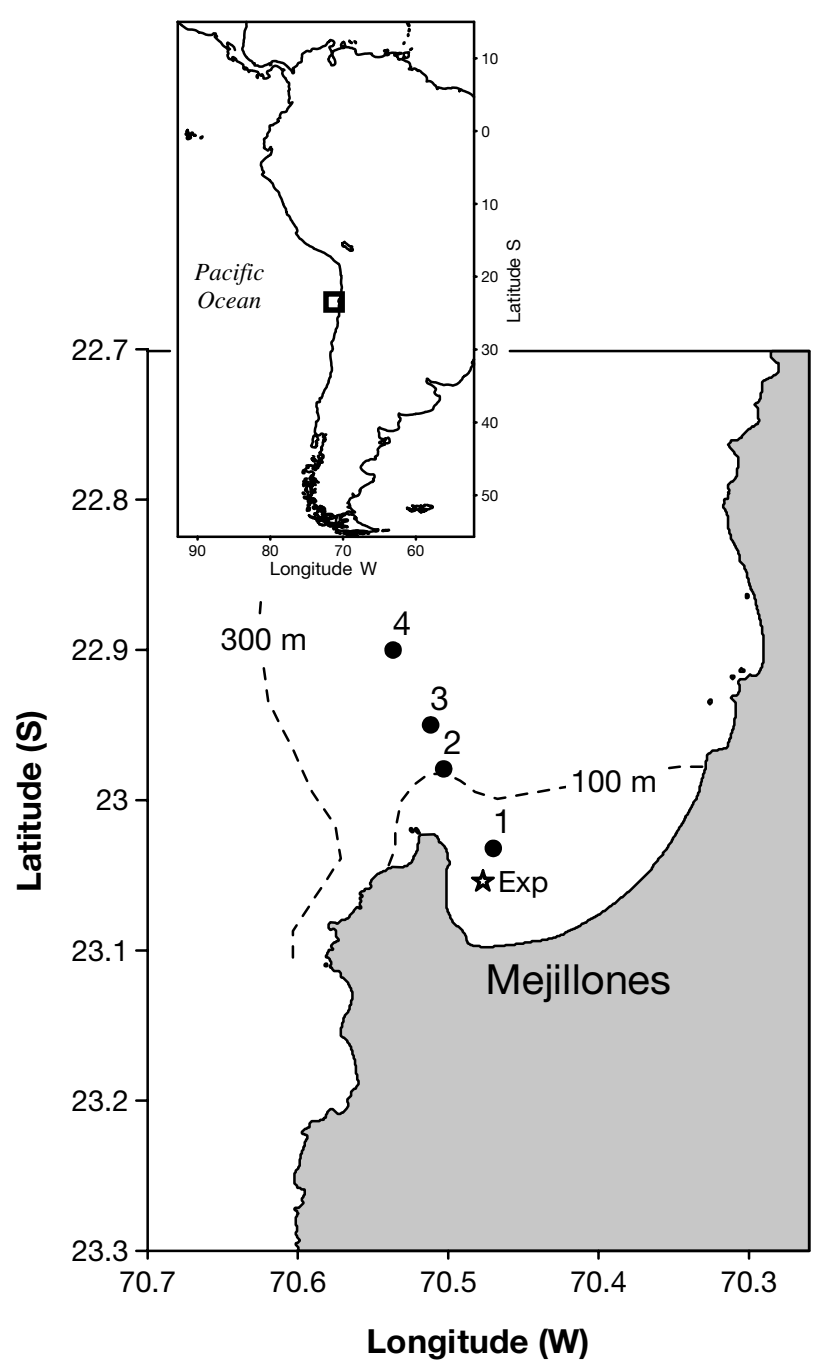

Fig. 1. Location of 4 sampling stations in Mejillones Bay. Isobaths are included. Stn Exp: station used in study of Vargas \& González (2003, this issue)

face using a SeaBird SBE-19 CTD equipped with an YSI-calibrated Beckman oxygen-sensor and a Westar fluorometer. Water samples for chlorophyll a $(\mathrm{chl} a)$, phytoplankton biomass, bacterial biomass, heterotrophic (h-) nanoflagellates, dinoflagellates and ciliates were collected at 1, 5, 10, 25, 50 and $100 \mathrm{~m}$ depths with 301 Niskin bottles (Table 1).

Phytoplankton biomass and production. Chl $a$ and phaeopigment concentration was measured after filtration of $500 \mathrm{ml}$ seawater, followed by extraction for $24 \mathrm{~h}$ in $90 \%$ acetone and fluorometric analysis (TD 700 Turner fluorometer) before and after acidification (Strickland \& Parsons 1972). Water samples for phytoplankton and protozoan cell counts were also collected with 301 Niskin bottles at 3 depths: 1, 25 and $50 \mathrm{~m}$. Cells were counted and measured $24 \mathrm{~h}$ after settling by inverted microscopy at $200 \times$ magnification (Uter- möhl 1958). Phytoplankton composition and biomass was determined by the methodology reported in Vargas \& González (2003).

Size-fractioned primary production was measured in parallel at a coastal station (Stn Exp) using the method of Steemann Nielsen (1952). In the present study, PP data has been used only to construct a carbon budget. For details of the methodology see Iriarte et al. (2000).

Bacteria, microprotozoan biomass, production and grazing. Samples for the determination of bacteria, microprotozoan and phytoplankton biomass were collected from the same Niskin bottles, and 3 depths were also chosen: 1, 25 and $50 \mathrm{~m}$. Bacteria, and autotrophic (a-) and heterotrophic (h-)nanoflagellates were quantified in 3 replicates from each sample by the acridine orange technique (Davis \& Sieburth 1982, Hobbie et al. 1977) and analyzed using a color imageanalysis system similar to that described by Verity \& Sieracki (1993). Autofluorescence of a-nanoflagellates was revealed by blue light excitation. Biovolume was converted to carbon using the equation of Simon \& Azam (1989) and Riemann \& Bell (1990). Samples of $\sim 100 \mathrm{ml}$ unfiltered seawater were preserved in $2 \%$ acid Lugol solution and refrigerated until counts of microprotozoans (ciliates, a- and h-dinoflagellates) could be made in the laboratory. Microprotozoans were counted and measured, and their carbon content was estimated according to the methods of Vargas \& González (2003). All naked dinoflagellates $>20 \mu \mathrm{m}$ were considered as heterotrophic (Hansen 1991, Levinsen et al. 1999).

We estimated protozoan (h-nanoflagellates, ciliates and h-dinoflagellates) ingestion with a model proposed by Peters (1994), since this model estimated of potential microprotozoan ingestion better than other models we tested previously (e.g. the temperaturedependent model of Vaqué et al. 1994, and the sizescaling model of Hansen et al. 1997), which did not consider important sources of variability such as prey and predator size. Peters' model predicts ingestion rates for a wide range of freshwater and marine ecosystems, and considers temperature, cell volumes, and concentrations of both prey and predator as explanatory variables:

$$
\begin{aligned}
& \log G R=2.701-0.344\left[\log V o l_{\text {prey }}\right]+0.477\left[\log V o l_{\text {predator }}\right] \\
& \quad+0.489\left[\log A B_{\text {prey }}\right]-0.270\left[\log A B_{\text {predator }}\right]+0.033 T
\end{aligned}
$$

where $G R=$ grazing rate $\left(\right.$ prey $\left.\mathrm{h}^{-1}\right) ; V_{\text {prey }}=$ biovolume of preys $\left(\mu \mathrm{m}^{3}\right) ; V o l_{\text {predator }}=$ biovolume of predators $\left(\mu \mathrm{m}^{3}\right)_{i}$ $A B_{\text {prey }}=$ abundance of preys $\left(\right.$ ind. $\left.1^{-1}\right) ; A B_{\text {predator }}=$ abundance of predators (ind. $\mathrm{l}^{-1}$ ), and $T=$ temperature $\left({ }^{\circ} \mathrm{C}\right.$ ).

Carbon demand $\left(\mathrm{mgC} \mathrm{m} \mathrm{m}^{-2} \mathrm{~d}^{-1}\right.$ ) was estimated for microprotozoan ingestion on a- and h-nanoflagellate 
and diatom prey, and integrated for the 0 to $25 \mathrm{~m}$ depth stratum. We attempted to predict predator-prey interactions on the basis that h-nanoflagellates feed mainly on bacteria and a-nanoflagellates, ciliates feed mainly on a- and h-nanoflagellates, and h-dinoflagellates feed mainly on diatoms. Since not all small choreotrich ciliates may feed efficiently on bacteria (Sherr et al. 1989, Kivi \& Setälä 1995), we took only bacterophagy into account for small aloricate ciliates. We could not estimate some feeding interactions, such as those of mixotrophic nanoflagellates, or of the abundant mixotrophic dinoflagellate Ceratium furca feeding on choreotrich ciliates (i.e. Strobidilium spp. and tintinnids; Smalley et al. 1999). A growth efficiency of $33 \%$ was used to calculate the production of protozooplankton (Hansen et al. 1997).

Zooplankton biomass and grazing. Vertical net hauls to estimate zooplankton abundance and biomass were done twice in 4 depth strata using a WP-2 net with $200 \mu \mathrm{m}$ mesh size, closing devices, and a calibrated General Oceanic flowmeter. The depth strata were 0-25, 25-50, 50-100 and 100-150 m (Table 1). In order to correct estimation of euphausiid abundance for evasion, additional oblique net hauls were done with a Bongo net (0.6 m mouth size) equipped with 200 and $500 \mu \mathrm{m}$ meshes and a calibrated flowmeter. All plankton samples were preserved immediately after collection with $5 \%$ formalin solution in seawater buffered with sodium borate. In the laboratory, subsamples (1/5 fraction) from the net-tows were counted, and the organisms identified and measured with a dissecting microscope. Biomass was calculated using lengthweight regressions of Klein Breteler et al. (1982) (Acartia sp. and Centropages sp.), Hirche \& Mumm (1992) (Oithona similis, Metridia spp.), Uye (1982) (other copepods), and Paffenhöfer (1976) and Gorsky et al. (1988) (Oikopleura spp.).

The grazing impact of zooplankton feeding on natural assemblages of protozoans (h-nano, dinoflagellates and ciliates), phytoplankton (diatoms, ananoflagellates and dinoflagellates) and bacteria were estimated using the ingestion rate data reported by Vargas \& González (2003) for dominant small copepods and appendicularians at Stn Exp (Fig. 1). Total ingestion by small copepods and appendicularians was calculated as the sum of the integrated abundance (0-25 $\mathrm{m}$ depth) of each species multiplied by the species-specific ingestion rate (estimated from incubation experiments). Since ingestion rates were estimated for the most abundant small copepod species and appendicularians (typically around 80 to $95 \%$ of the total biomass of each group), this was assumed to represent the total grazing impact by the small copepod and appendicularian communities.

\section{RESULTS}

\section{Hydrography}

Vertical cross-sections showed that in February and October the water column in the study area was thermally stratified down to 20 to $25 \mathrm{~m}$ depth, with a gradient of 14 to $18^{\circ} \mathrm{C}$ (Fig. 2a, g), while during August the water column was more mixed (Fig. 2d). On all sampling occasions, salinity was relatively uniform throughout the whole water column (Fig. 2b, e, h). In February and October, the $14^{\circ} \mathrm{C}$ isoline rose from $\sim 40$ to $\sim 15 \mathrm{~m}$ depth in an offshore-inshore direction suggesting that despite the stratification, a moderate wind-driven upwelling might have developed in the area around Mejillones peninsula. In fact, the depth of the oxygen minimum layer (OML; defined here as $\leq 0.5 \mathrm{ml} \mathrm{O}_{2} \mathrm{l}^{-1}$ ) also rose nearshore, and during February and August was located at $\sim 30 \mathrm{~m}$ depth (Fig. 2c, f). Conversely, in October the OML depth remained in deep waters at $\sim 60$ to $70 \mathrm{~m}$ depth (Fig. 2i).

\section{Phytoplankton biomass}

A dominant feature during the whole sampling period was the occurrence of the highest chl a concentration near the surface (upper 20 to $30 \mathrm{~m}$ ) and always associated with Stn 1, inside Mejillones Bay (Fig. 2c, f, i). The highest chl a concentrations were found during the August sampling, with concentrations up to $35 \mathrm{mg} \mathrm{m}^{-3}$ in surface waters (Fig. 2f). At this time, high chl a concentrations (15 to $20 \mathrm{mg} \mathrm{m}^{-3}$ ) were also observed along the transect. In October, surface chl a concentrations were the lowest of the entire study period $\left(\sim 2 \mathrm{mg} \mathrm{m}^{-3}\right)$ (Fig. 2i). Most of the chl a biomass was restricted to the well-oxygenated upper 25 m layer.

In general, diatoms dominated phytoplankton biomass at all stations and on all sampling occasions. However, there were marked differences in species composition between the different sampling occasions. In February, the dominant genera and species (>25\% of the identified cells) were Chaetoceros spp., Cylindrotheca spp. and Guinardia delicatula. In the August sampling, the phytoplankton was dominated by a bloom of the chain-forming diatoms $G$. delicatula and Detonula pumila, with individual cells $<30 \mu \mathrm{m}$. In October, diatoms were represented mostly by Eucampia cornuta and Chaetoceros socialis. Despite the small area covered by our study, there was a high spatial patchiness along the transect, with the contribution of diatoms to carbon biomass differing among close stations. The highest diatom biomass was observed outside of the bay, at Stn 2 in February and at Stn 3 in August (Fig. 3a, b). Varying C:chl ratios were evident 

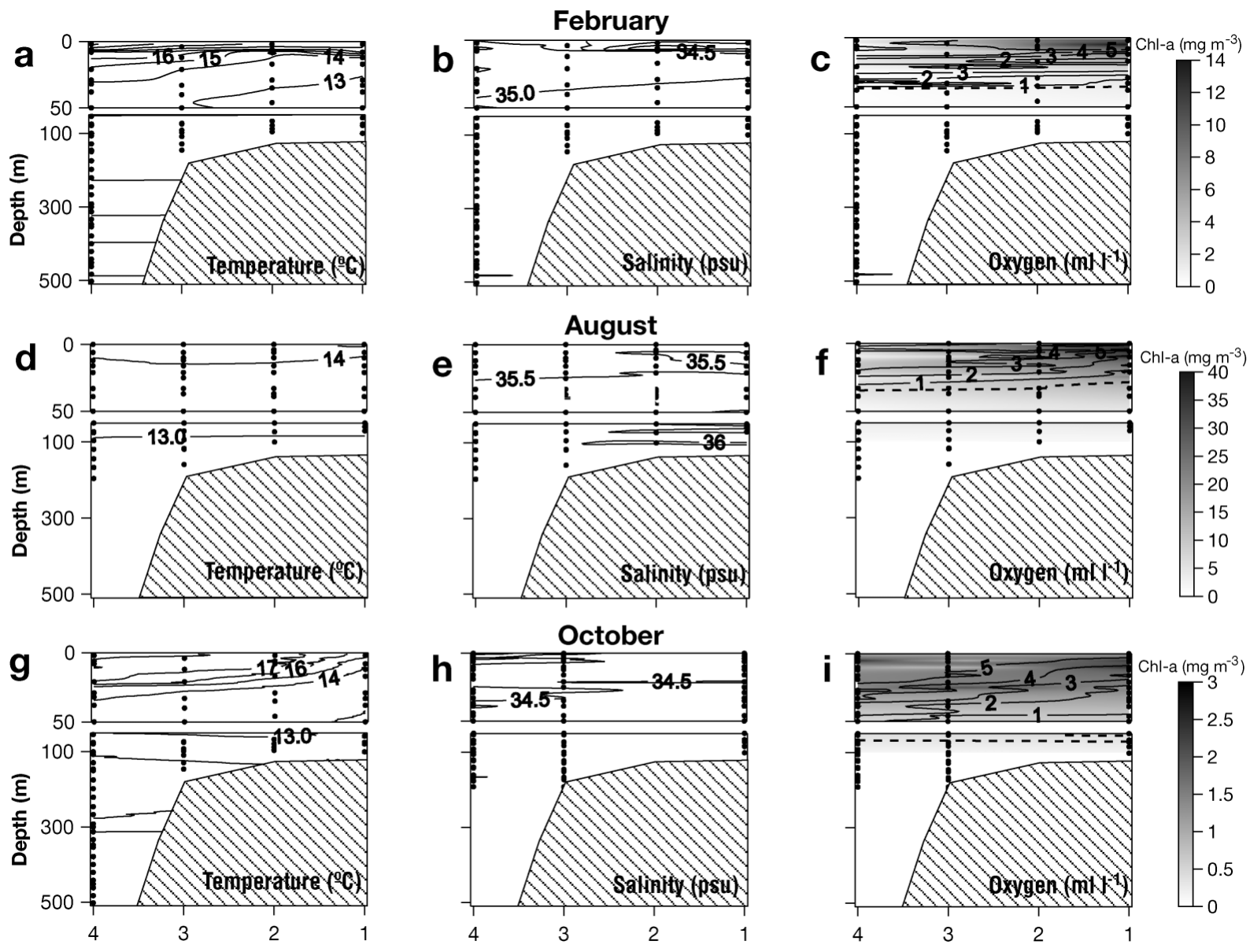

Fig. 2. Isopleths of $(a, d, g)$ temperature, $(b, e, h)$ salinity, $(c, f, i)$ oxygen and chlorophyll a on (a, b, c) February, (d, e, f) August and $(g, h, i)$ October 2001 sampling occasions. Dotted line in plots (c), (f) and (i) represents depth of oxygen minimum layer, defined here as $0.5 \mathrm{ml} \mathrm{O}_{2} \mathrm{l}^{-1}$

along the transect in August, as maximum chl a concentration did not match with highest cell biomass (Fig. 2f, 3b). A-nanoflagellates were more abundant inside Mejillones Bay (Stn 1). The contribution of ananoflagellates to the total biomass at this station was particularly significant during the February sampling (Fig. 3a), with a biomass even higher than that of diatoms, with a dominance of cells $>5 \mu \mathrm{m}$. The biomass of a-dinoflagellates was represented mostly by large armored Ceratium species, and highest values were observed during the August sampling (Fig. 3b).

\section{Bacteria and protozoan biomass, production and grazing}

The depth-integrated bacterial biomass (i.e. 0 to $50 \mathrm{~m} \mathrm{depth}$ ) was on the order of 0.05 to $0.7 \mathrm{~g} \mathrm{C} \mathrm{m}^{-2}$, and the highest biomass was, on average, observed during the August sampling (Figs. 3b \& 4). Most bacterial bio- mass was associated with productive surface waters (i.e. the upper $5 \mathrm{~m}$ layer) and the OML at $50 \mathrm{~m}$ depth (Fig. 4). H-nanoflagellate biomass ranged between 0.1 and $2.5 \mathrm{~g} \mathrm{C} \mathrm{m}^{-2}$, with maximum values inside the bay (Stn 1) during February and August (Fig. 3a). Ciliates and h-dinoflagellate biomass was relatively low on all sampling occasions. The ciliates present consisted primarily of the large tintinnids Helicostomella spp., Eutintinnus spp. and Tintinnopsis spp. and some aloricate choreotrichs Strombidium spp. Although the ciliate biomass was low, it was significantly higher at the slope stations (Stns 2 and 3) than inside the bay (Stn 1) ( $t$-test; 1 -tailed; $\mathrm{p}=0.007$ ) (Fig. 3 , see also Tables $3 \&$ 4). Thecate forms dominated h-dinoflagellates $>20 \mu \mathrm{m}$, with Protoperidinium spp. and the myxotroph Prorocentrum micans constituting the dominant genera. Maximum biomass of ciliates and h-dino flagellates was observed in February at Stn 2 ( 1600 mg C m-2). Most of the protozoan biomass inside Mejillones Bay was restricted to surface waters, with values between 

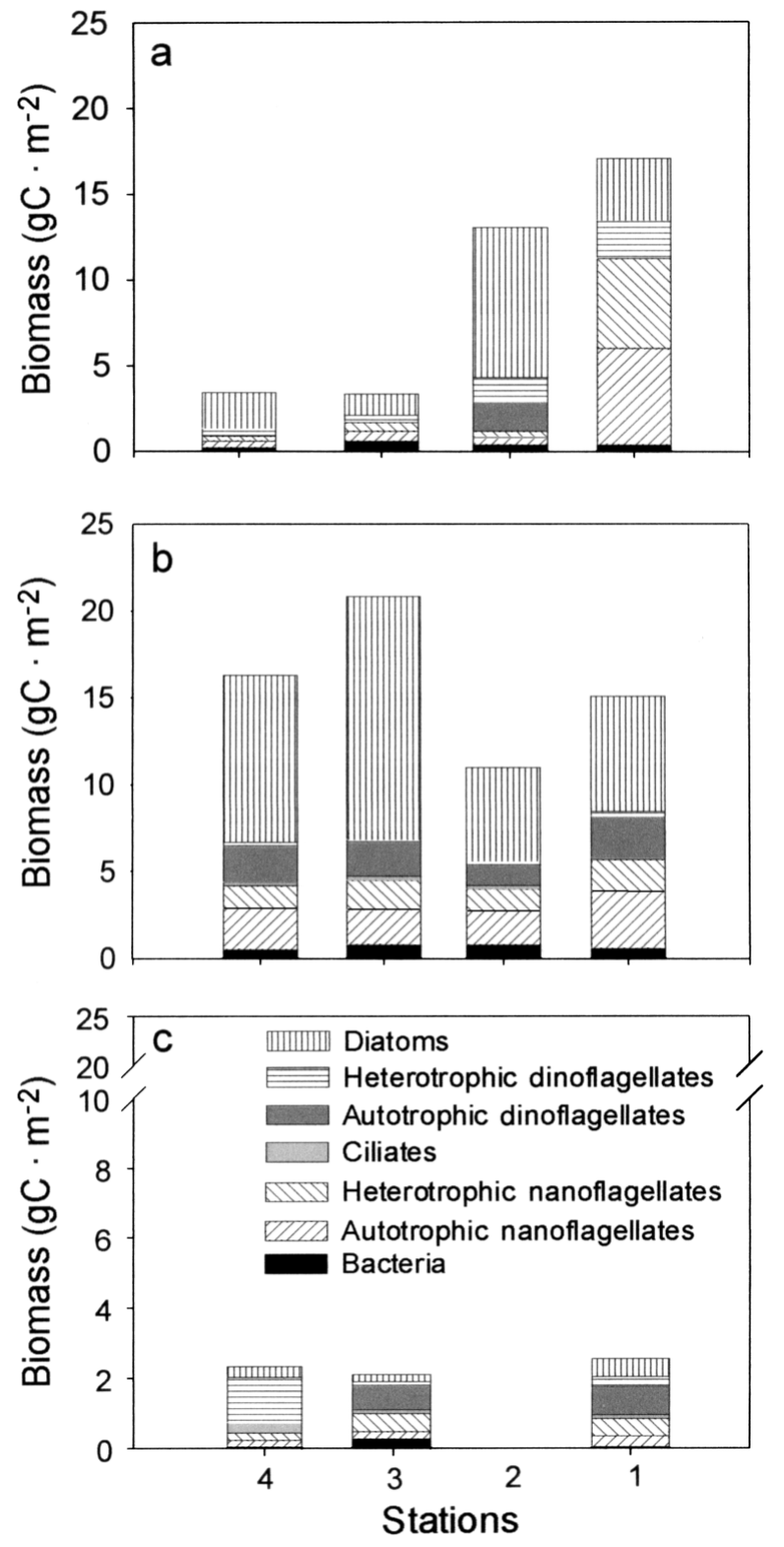

Fig. 3. Mean contribution of major taxonomic groups to integrated ( 0 to $50 \mathrm{~m}$ depth) biomass $\left(\mathrm{g} \mathrm{C} \mathrm{m}^{-2}\right)$ of autotrophic and heterotrophic community along transect on (a) February, (b) August and (c) October 2001 sampling occasions (average of

Legs 1 and 2). Note different y-axis in October plot

10 and $150 \mathrm{mgC} \mathrm{m}^{-3}$ ( $t$-test; 1 -tailed; $\mathrm{p}=0.0008$ ). The highest biomass was observed during the February sampling (Fig. 4).

Estimates of grazing by protozoans showed that h-nanoflagellates may ingest from 12 to 76 bacteria ind. ${ }^{-1} \mathrm{~h}^{-1}$, similarly to many reports for different marine ecosystems (Table 2). We presumed that only small aloricate ciliates were feeding on bacteria, and values ranged between $\sim 270$ and 660 bacteria ciliate ${ }^{-1} \mathrm{~h}^{-1}$. Ciliate ingestion of a- and h-nanoflagellates was rela-

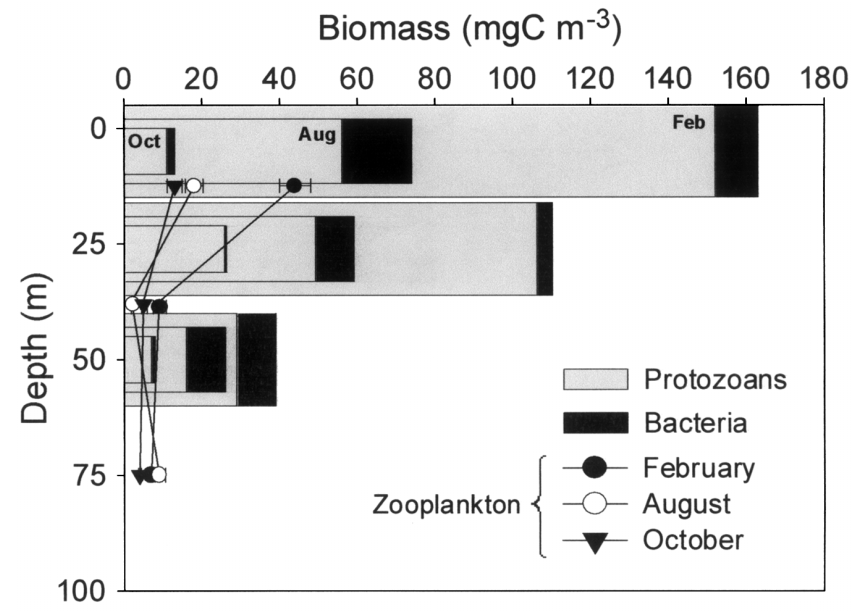

Fig. 4. Vertical distribution of bacteria, protozoan and zooplankton biomass $\left(\mathrm{mgC} \mathrm{m}^{-3}\right)$ at Stn 1, inside Mejillones Bay, on the 3 sampling occasions. Differences in bar width distinguish sampling period. Errors bars $=\mathrm{SD}$

tively low ( $\sim 1$ to 20 cells ciliate ${ }^{-1} \mathrm{~h}^{-1}$, Table 2 ). Ingestion of diatoms by $\mathrm{h}$-dinoflagellates was $\sim 0.5$ cells ind. ${ }^{-1} \mathrm{~h}^{-1}$, which also fits well within the range of values reported in the literature (Table 2). Production of protozooplankton was closely associated with biomass level, with a high spatial heterogeneity for each protozoan group. However, maximum total protozooplankton production mainly occurred nearshore at Stns 1 and 2 (Tables 3, 4 \& 5). H-dinoflagellates played a major role in phytoplankton consumption, with the highest carbon demand by protozooplankton (ANOVA, $p<0.01$ ). The highest total grazing impact by protozooplankton was observed inside the bay, except in October, when grazing was slightly higher at Stn 4 than at Stn 1 ( $t$-test: $\mathrm{p}<0.05$ ) (Tables 3, 4, \& 5). Inside Mejillones Bay, protozooplankton ingested between 350 and $2500 \mathrm{mg} \mathrm{C} \mathrm{m}^{-2} \mathrm{~d}^{-1}$.

\section{Zooplankton biomass and grazing}

Copepods were the dominant components of the zooplankton biomass in the study area. A total of 13 genera or species were identified in the samples. Small calanoid and cyclopoid copepods were the dominant group comprising 64,48 and $72 \%$ of the total biomass inside Mejillones Bay in February, August and October respectively. Paracalanus parvus, Acartia tonsa, Centropages brachiatus and Oithona similis were the dominant species in this group, especially inside Mejillones Bay (Stn 1) (Table 6). The contribution of large copepods (e.g. Calanus chilensis and Eucalanus sp.) was slightly higher than that of small copepods only during 
February and October at Stn 4 (ANOVA; $\mathrm{p}<0.05$ ) (Table 6). The distribution of copepods reflected the increase in phytoplankton biomass rather than chl a concentration, with the highest biomass at Stns 1 and 3 in February, Stns 2 and 3 in August and Stn 1 in October. Appendicularians, mostly dominated by the species
Oikopleura dioica, constituted around $5 \%$ of the total biomass inside the bay during February (64.4 mgC $\mathrm{m}^{-2}$ ). During August, another coastal appendicularian species, O. longicauda, constituted around $7 \%$ of the total biomass inside the bay (Table 6: 'Appendicularians'). This species was also very abundant on the shelf

Table 2. Feeding data for flagellates, ciliates and dinoflagellates from this study, 2001 (Peters' 1944 model) and from the literature. HNF: heterotrophic nanoflagellates; ANF: autotrophic nanoflagellates

\begin{tabular}{|c|c|c|c|c|}
\hline Species & $\begin{array}{c}\text { Ingestion } \\
\left(\text { cell pred }^{-1} \mathrm{~h}^{-1}\right)\end{array}$ & Species & $\begin{array}{l}\text { Nos. } \\
\left(\times 10^{6} \mathrm{ml}^{-1}\right)\end{array}$ & Source \\
\hline \multicolumn{5}{|l|}{ Flagellates } \\
\hline Mixed HNF > $5 \mu \mathrm{m}$ & $\begin{array}{l}24-64 \\
28-63 \\
12-76\end{array}$ & $\begin{array}{l}\text { Mixed bacteria } \\
\text { Mixed bacteria } \\
\text { Mixed bacteria }\end{array}$ & $\begin{array}{l}0.1-0.4 \\
0.5-1 \\
0.3-1\end{array}$ & $\begin{array}{l}\text { This study, February }\left(16^{\circ} \mathrm{C}\right) \\
\text { This study, August }\left(14^{\circ} \mathrm{C}\right) \\
\text { This study, October }\left(15^{\circ} \mathrm{C}\right)\end{array}$ \\
\hline Mixed HNF & 54 & Mixed bacteria & $0.2-1.4$ & Cuevas (1999) $\left(9.5-13^{\circ} \mathrm{C}\right)$ \\
\hline $\begin{array}{l}\text { Monosiga sp. } \\
\text { Pseudobodo tremulans }\end{array}$ & $\begin{array}{l}27 \\
84\end{array}$ & $\begin{array}{l}\text { Pseudomonas spp. } \\
\text { Pseudomonas spp. }\end{array}$ & $\begin{array}{l}5-35 \\
5-50\end{array}$ & $\begin{array}{l}\text { Fenchel (1982): batch } \\
\text { cultures at } 20^{\circ} \mathrm{C}\end{array}$ \\
\hline Monas spp. & $10-75$ & Mixed bacteria & $25-8000$ & Sherr et al. (1983) \\
\hline $\begin{array}{l}\text { Pseudobodo tremularis } \\
\text { Pseudobodo sp. }\end{array}$ & $45-73$ & $\begin{array}{l}\text { Mixed bacteria } \\
\text { Mixed bacteria }\end{array}$ & $2.4-4.8^{*}$ & Andersen \& Fenchel (1985) ${ }^{\text {a }}$ \\
\hline Mixed HNF & $5-28$ & $\begin{array}{l}\text { Fluorescently } \\
\text { labeled bacteria }\end{array}$ & $2.5-9.2$ & $\begin{array}{l}\text { Sherr et al. (1988): } \\
12-20^{\circ} \mathrm{C}\end{array}$ \\
\hline $\begin{array}{l}\text { Spurnella sp. } \\
\text { Cafeteria sp. }\end{array}$ & $\begin{array}{r}12-48 \\
2-14\end{array}$ & $\begin{array}{l}\text { Synechococcus spp. } \\
\text { Synechococcus spp. }\end{array}$ & $\begin{array}{l}10-12 \\
10-12\end{array}$ & $\begin{array}{l}\text { Boenigk et al. (2001): } \\
18-20^{\circ} \mathrm{C}\end{array}$ \\
\hline \multirow{2}{*}{$\begin{array}{l}\text { Ciliates } \\
\text { Mixed ciliates }\end{array}$} & & & $\left(\times 10^{3} \mathrm{ml}^{-1}\right)$ & \\
\hline & $\begin{array}{c}305-592 \\
479-647 \\
270-663 \\
6-15 \\
6-21 \\
1-11 \\
13 \\
11 \\
6\end{array}$ & $\begin{array}{l}\text { Mixed bacteria } \\
\text { Mixed bacteria } \\
\text { Mixed bacteria } \\
\text { Mixed ANF } \\
\text { Mixed ANF } \\
\text { Mixed ANF } \\
\text { Mixed HNF } \\
\text { Mixed HNF } \\
\text { Mixed HNF }\end{array}$ & $\begin{array}{l}0.1-0.4 \\
0.5-1 \\
0.3-1 \\
0.4-4 \\
0.7-5 \\
0.01-0.4 \\
0.9-10 \\
0.7-2 \\
0.2-0.6\end{array}$ & $\begin{array}{l}\text { This study, February } \\
\text { This study, August } \\
\text { This study, October } \\
\text { This study, February } \\
\text { This study, August } \\
\text { This study, October } \\
\text { This study, February } \\
\text { This study, August } \\
\text { This study, October }\end{array}$ \\
\hline $\begin{array}{l}\text { Strobilidium hexakinetum } \\
\text { Halteria grandinella }\end{array}$ & $\begin{array}{l}110-650 \\
470-2690\end{array}$ & $\begin{array}{l}\text { Mixed bacteria } \\
\text { Mixed bacteria }\end{array}$ & & Šimek et al. (1996) \\
\hline Strombidium sulcatum & $900-926$ & $\begin{array}{l}\text { Prochlorocococcus + } \\
\text { Synechococcus spp. }\end{array}$ & 500 & Christaki et al. (1999) \\
\hline $\begin{array}{l}\text { Tintinnopsis acuminata } \\
\text { Tintinnopsis vasculum }\end{array}$ & $\begin{array}{l}29-80 \\
34-83\end{array}$ & $\begin{array}{l}\text { Isochrysis spp. } \\
\text { Dicrateria spp. }\end{array}$ & & Verity (1985) \\
\hline $\begin{array}{l}\text { Uronema marina } \\
\text { Mixed spirotrichs }\end{array}$ & $\begin{array}{l}710 \\
380\end{array}$ & $\begin{array}{l}\text { Fluorescently } \\
\text { labeled bacteria }\end{array}$ & $\begin{array}{c}14400 \\
1500\end{array}$ & $\begin{array}{l}\text { Sherr et al. (1988): } \\
19.5-22^{\circ} \mathrm{C}\end{array}$ \\
\hline $\begin{array}{l}\text { Strombidium vestitum } \\
\text { Rimostrombidium conicum }\end{array}$ & $\begin{array}{l}\sim 17-25 \\
\sim 20-75\end{array}$ & $\begin{array}{l}\text { Isochrysis galbana } \\
\text { or Phaeocystis globosa }\end{array}$ & & Tang et al. (2001) \\
\hline Dinoflagellates & & & $\left(\mathrm{ml}^{-1}\right)$ & \\
\hline $\begin{array}{l}\text { Mixed H-dinoflagellates } \\
\text { (mostly Protoperidinium) }\end{array}$ & $\begin{array}{l}0.4 \\
0.4 \\
0.5\end{array}$ & $\begin{array}{l}\text { Mixed diatoms } \\
\text { Mixed diatoms } \\
\text { Mixed diatoms }\end{array}$ & $\begin{array}{l}5-25 \\
1-5 \\
0.9-3\end{array}$ & $\begin{array}{l}\text { This study, February } \\
\text { This study, August } \\
\text { This study, October }\end{array}$ \\
\hline Protoperidinium & $0.08-0.2$ & Red tide dinoflagellates & & Jeong \& Latz (1994) \\
\hline Gyrodinium galatheanum & $0-0.01$ & Mixed cryptophytes & & Li et al. (2001) \\
\hline
\end{tabular}


Table 3. Integrated distribution of biomass, production and ingestion of auto- and heterotrophs ( $\mathrm{H}-$ ) across transect in Mejillones Bay area in February 2001. Data integrated for oxygenated upper $25 \mathrm{~m}$ of water column. PP: primary production

\begin{tabular}{|c|c|c|c|c|}
\hline \multirow[t]{2}{*}{ Species } & \multicolumn{4}{|c|}{ Station } \\
\hline & 1 & 2 & 3 & 4 \\
\hline \multicolumn{5}{|l|}{ Biomass (mg C m²) } \\
\hline Phytoplankton & 6376 & 5671 & 846 & 351 \\
\hline Bacteria & 202 & 146 & 230 & 54 \\
\hline H-nanoflagellates & 2540 & 246 & 242 & 118 \\
\hline Ciliates & 15 & 1660 & 5 & 5 \\
\hline H-dinoflagellates & 23 & 1658 & 0 & 0 \\
\hline Small copepods & 768 & 427 & 704 & 64 \\
\hline Medium-large copepods & 217 & 171 & 675 & 198 \\
\hline Appendicularians & 58 & 6 & 32 & 3 \\
\hline Euphausiids & 33 & 0 & 0 & 0 \\
\hline \multicolumn{5}{|l|}{ Production $\left(\mathrm{mg} \mathrm{C} \mathrm{m}^{-2} \mathrm{~d}^{-1}\right)$} \\
\hline Phytoplankton & $5566^{\mathrm{a}}$ & & & \\
\hline H-nanoflagellates & 6764 & 654 & 645 & 314 \\
\hline Ciliates & 21 & 2366 & 7 & 7 \\
\hline H-dinoflagellates & 24 & 1703 & 0 & 0 \\
\hline \multicolumn{5}{|l|}{ Ingestion $\left(\mathrm{mg} \mathrm{C} \mathrm{m}^{-2} \mathrm{~d}^{-1}\right)$} \\
\hline H-nanoflagellates & 401 & 172 & 146 & 76 \\
\hline Ciliates & 753 & 281 & 223 & 229 \\
\hline H-dinoflagellates & 1351 & 900 & 0 & 0 \\
\hline Total & 2505 & 1353 & 369 & 305 \\
\hline$\% P P \Rightarrow$ protozooplankton & 45.0 & & & \\
\hline Small copepods & 108 & 80 & 151 & 21 \\
\hline Appendicularians & 34 & 3 & 14 & 1 \\
\hline Euphausiids & 2 & 0 & 0 & 0 \\
\hline Total & 144 & 83 & 165 & 22 \\
\hline$\% P P \Rightarrow$ zooplankton & 2.6 & & & \\
\hline${ }^{a}$ Unpubl. data of J. Iriarte 8 & Gon & & & \\
\hline
\end{tabular}

(Stn 3), with an integrated biomass of $87 \mathrm{mg} \mathrm{C} \mathrm{m}^{-2}$ in the upper $25 \mathrm{~m}$ depth (12\% of the total biomass) (Table 4). Euphausiids were infrequently collected in samples taken with both the WP-2 and Bongo nets, and very few specimens were caught in February. Therefore we did not consider this group as significant grazers during our study (Table 4). The zooplankton community was mainly present in the well-oxygenated upper $25 \mathrm{~m}$, where biomass ranged between 10 and $45 \mathrm{mgC} \mathrm{m}^{-3}$. Maximum biomass was observed during February, and decreased with depth below the surface (Fig. 4). Small copepods accounted for the highest carbon consumption on autotrophs ( $t$-test: $\mathrm{p}=0.005)$. Inside Mejillones Bay, appendicularians ingested only between 25 and $34 \mathrm{mg} \mathrm{C} \mathrm{m}^{-2} \mathrm{~d}^{-1}$ (Tables $3 \& 4$ ) and the maximum carbon ingestion by appendicularians $\left(\sim 72 \mathrm{mg} \mathrm{C} \mathrm{m}^{-2} \mathrm{~d}^{-1}\right)$ was observed in August at Shelf Stn 3. Total zooplankton carbon consumption was higher at Stn 3 during February and August, and at Stn 1 during October. Inside Mejillones Bay, the total zooplankton ingested between 63 and $144 \mathrm{mg} \mathrm{C} \mathrm{m}^{-2} \mathrm{~d}^{-1}$ in the upper $25 \mathrm{~m}$ depth, with maximum ingestion in February.
Table 4. Integrated distribution of biomass, production and ingestion of auto- and heterotrophs ( $\mathrm{H}-$ ) across transect in Mejillones Bay area in August 2001. Data integrated for oxygenated upper $25 \mathrm{~m}$ of water column. PP: primary production

\begin{tabular}{|c|c|c|c|c|}
\hline \multirow[t]{2}{*}{ Species } & \multicolumn{4}{|c|}{ Station } \\
\hline & 1 & 2 & 3 & 4 \\
\hline \multicolumn{5}{|l|}{ Biomass $\left(\mathrm{mg} \mathrm{C} \mathrm{m}^{-2}\right)$} \\
\hline Phytoplankton & 9250 & 5637 & 17235 & 8680 \\
\hline Bacteria & 359 & 423 & 615 & 316 \\
\hline H-nanoflagellates & 1113 & 537 & 945 & 567 \\
\hline Ciliates & 77 & 89 & 118 & 132 \\
\hline H-dinoflagellates & 144 & 88 & 63 & 121 \\
\hline Small copepods & 202 & 544 & 440 & 180 \\
\hline Medium-large copepods & 120 & 88 & 131 & 20 \\
\hline Appendicularians & 30 & 62 & 87 & 0 \\
\hline Euphausiids & 0 & 0 & 65 & 17 \\
\hline \multicolumn{5}{|l|}{ Production $\left(\mathrm{mg} \mathrm{C} \mathrm{m}^{-2} \mathrm{~d}^{-1}\right)$} \\
\hline Phytoplankton & $9415^{a}$ & & & \\
\hline H-nanoflagellates & 2964 & 1429 & 2517 & 1509 \\
\hline Ciliates & 109 & 127 & 169 & 188 \\
\hline H-dinoflagellates & 147 & 99 & 65 & 124 \\
\hline \multicolumn{5}{|l|}{ Ingestion $\left(\mathrm{mgC} \mathrm{m}^{-2} \mathrm{~d}^{-1}\right)$} \\
\hline H-nanoflagellates & 39 & 18 & 28 & 11 \\
\hline Ciliates & 1013 & 853 & 655 & 741 \\
\hline H-dinoflagellates & 1360 & 1335 & 0 & 559 \\
\hline Total & 2412 & 2206 & 683 & 1311 \\
\hline$\% P P \Rightarrow$ protozooplankton & 26 & & & \\
\hline Small copepods & 61 & 103 & 120 & 42 \\
\hline Appendicularians & 25 & 51 & 72 & 0 \\
\hline Euphausiids & 0 & 0 & 4 & 1 \\
\hline Total & 86 & 154 & 196 & 43 \\
\hline$\% P P \Rightarrow$ zooplankton & 1 & & & \\
\hline \multicolumn{5}{|c|}{ a Unpubl. data of J. Iriarte \& H. González } \\
\hline
\end{tabular}

\section{DISCUSSION}

\section{Hydrography and productivity}

The physical environment of the Mejillones Bay area has been characterized in previous studies (Navea \& Miranda 1980, Rodríguez et al. 1991, Marín et al. 2001, Sobarzo \& Figueroa 2001), in which the development of quasi-permanent upwelling events along the Mejillones Peninsula was described. During the period of our study, the temperature and oxygen distribution suggested the occurrence of upwelling events in February and October. In these periods the OML penetrated the upper $30 \mathrm{~m}$ depth layer inside the bay. Previous studies (Morales et al. 1996, Escribano 1998) indicated that low-oxygen waters may reach 40 to $60 \mathrm{~m}$ depth in this area. Furthermore, October corresponds to the time of maximum upwelling (Marín \& Olivares 1999). Such periods of low oxygen are typically characterized by high nitrate concentrations (Rodríguez et al. 1991), and thus may have enhanced primary production in the area. In 
Table 5. Integrated distribution of biomass, production and ingestion of auto- and heterotrophs ( $\mathrm{H}-$ ) across transect in Mejillones Bay area in October 2001. Data integrated for oxygenated upper $25 \mathrm{~m}$ of water column. PP: primary production

\begin{tabular}{|c|c|c|c|}
\hline \multirow[t]{2}{*}{ Species } & \multicolumn{3}{|c|}{ Station } \\
\hline & 1 & 3 & 4 \\
\hline \multicolumn{4}{|l|}{ Biomass $\left(\mathrm{mg} \mathrm{C} \mathrm{m}^{-2}\right)$} \\
\hline Phytoplankton & 752 & 522 & 1514 \\
\hline Bacteria & 33 & 98 & 31 \\
\hline H-nanoflagellates & 266 & 294 & 102 \\
\hline Ciliates & 35 & 43 & 198 \\
\hline H-dinoflagellates & 132 & 74 & 5 \\
\hline Small copepods & 237 & 165 & 118 \\
\hline Medium-large copepods & 23 & 43 & 23 \\
\hline Appendicularians & 2 & 2 & 1 \\
\hline Euphausiids & 63 & 0 & 0 \\
\hline \multicolumn{4}{|l|}{ Production $\left(\mathrm{mgC} \mathrm{m}^{-2} \mathrm{~d}^{-1}\right)$} \\
\hline Phytoplankton & $1124^{*}$ & & \\
\hline H-nanoflagellates & 708 & 784 & 272 \\
\hline Ciliates & 50 & 62 & 283 \\
\hline H-dinoflagellates & 136 & 76 & 5 \\
\hline \multicolumn{4}{|l|}{ Ingestion $\left(\mathrm{mgC} \mathrm{m}^{-2} \mathrm{~d}^{-1}\right)$} \\
\hline H-nanoflagellates & 116 & 187 & 84 \\
\hline Ciliates & 76 & 92 & 317 \\
\hline H-dinoflagellates & 157 & 77 & 76 \\
\hline Total & 349 & 356 & 477 \\
\hline$\% P P \Rightarrow$ protozooplankton & 31 & & \\
\hline Small copepods & 57 & 35 & 26 \\
\hline Appendicularians & 1 & 1 & 0.5 \\
\hline Euphausiids & 5 & 0 & 0 \\
\hline Total & 63 & 36 & 26.5 \\
\hline$\% P P \Rightarrow$ zooplankton & 6 & & \\
\hline${ }^{a}$ Unpubl. data of J. Iriarte \& & Gonzá & & \\
\hline
\end{tabular}

fact, phytoplankton biomass was very high during our study, in agreement with data from other studies (e.g. Marín \& Olivares 1999). The biomass was dominated by chain-forming diatoms, with maximum values inside Mejillones Bay and the shelf area (Stn 3).

Primary production and microphytoplankton biomass are usually high in the euphotic zone of the study area (Marín \& Olivares 1999). The depth of the euphotic zone inside Mejillones Bay is around 10 to $40 \mathrm{~m}$ (Rodríguez et al. 1991). During our study, the mean euphotic layer (measured by Secchi disk, Table 1) occurred at around 20 to $25 \mathrm{~m}$ depth. Integrated PP in the euphotic zone (J. Iriarte \& H. González unpubl.), was 5.5, 9.4, and $1.1 \mathrm{~g} \mathrm{C} \mathrm{m}^{-2} \mathrm{~d}^{-1}$, during February, August and October respectively, values that are among the highest reported for this area, and microphytoplankton $>23 \mu \mathrm{m}$ accounted for $>50 \%$ of the PP over the whole study period.
Table 6. Integrated biomass $\left(\mathrm{mg} \mathrm{C} \mathrm{m}^{-2}\right.$ ) of zooplankton in upper $50 \mathrm{~m}$ depth layer in coastal and oceanic stations during different sampling periods

\begin{tabular}{|c|c|c|c|c|}
\hline Taxon & February & August & October & Mean (SE) \\
\hline \multicolumn{5}{|l|}{ Coastal stations } \\
\hline \multicolumn{5}{|l|}{ Small-medium copepods } \\
\hline Paracalanus parvus & 625.7 & 134.9 & 288.1 & $349.6(251.1)$ \\
\hline Acrocalanus sp. & 0.9 & 1.5 & 0 & $08(0.7)$ \\
\hline Acartia tonsa & 131.4 & 52.5 & 1.2 & $61.7(65.6)$ \\
\hline Centropages brachiatus & 48.3 & 12.1 & 17 & $25.8(19.6)$ \\
\hline Temora longicornis & 0.5 & 0 & 0 & $0.2(0.3)$ \\
\hline Oithona similis & 2.1 & 4.3 & 4.8 & $3.7(1.4)$ \\
\hline Oncaea sp. & 29.8 & 7.4 & 9.3 & $15.5(12.4)$ \\
\hline Corycaeus anglicus & 2.4 & 0.3 & 9.9 & $4.2(5.1)$ \\
\hline Clytemnestra sp. & 0.3 & 0 & 0 & $0.1(0.1)$ \\
\hline Copepodids $(>500 \mu \mathrm{m})$ & 0.6 & 0.7 & 0 & $0.4(0.4)$ \\
\hline Total & 841.9 & 213.7 & 330.3 & $462(356.8)$ \\
\hline \multicolumn{5}{|l|}{ Large copepods } \\
\hline Calanus chilensis & 56.4 & 94.1 & 28.2 & $72.9(54.8)$ \\
\hline Eucalanus sp. & 274.6 & 45.4 & 6.1 & $112.0(143.0)$ \\
\hline Candacia sp. & 0 & 20.4 & 0 & $6.8(11.8)$ \\
\hline Metridia longa & 8.7 & 1.4 & 0.3 & $3.5(4.5)$ \\
\hline Total & 339.8 & 161.3 & 34.6 & $195.2(214.1)$ \\
\hline Appendicularians & 64.4 & 32.6 & 7 & $34.7(28.8)$ \\
\hline \multicolumn{5}{|l|}{ Euphausiids } \\
\hline Adults & 43.4 & 0 & 0 & $14.5(25.1)$ \\
\hline Juvenile & 0 & 0 & 63.1 & $21.0(36.4)$ \\
\hline Calyptopis & 13.6 & 32.7 & 1.5 & $16.0(15.7)$ \\
\hline Furcilia & 6.8 & 4.5 & 21.7 & 11. $0(9.3)$ \\
\hline Total & 63.9 & 37.2 & 86.3 & $62.5(86.6)$ \\
\hline \multicolumn{5}{|l|}{ Oceanic stations } \\
\hline \multicolumn{5}{|l|}{ Small-medium copepods } \\
\hline Paracalanus parvus & 80.1 & 125.3 & 99.5 & $101.0(22.7)$ \\
\hline Acrocalanus sp. & 1.1 & 0 & 0.4 & $0.5(0.6)$ \\
\hline Acartia tonsa & 3.5 & 19.8 & 1.4 & $8.2(10.1)$ \\
\hline Centropages brachiatus & 0 & 7.3 & 2.0 & $3.1(3.8)$ \\
\hline Temora longicornis & 0.8 & 0 & 0.7 & $0.5(0.4)$ \\
\hline Oithona similis & 2.7 & 1.4 & 1.9 & $2.0(0.7)$ \\
\hline Oncaea sp. & 9.7 & 1.0 & 11.6 & $7.4(5.6)$ \\
\hline Corycaeus anglicus & 3.3 & 0.5 & 4.6 & $2.8(2.1)$ \\
\hline Clytemnestra sp. & 0 & 0 & 0 & 0 \\
\hline Copepodids $(>500 \mu \mathrm{m})$ & 0.3 & 0.1 & 0 & $0.2(0.2)$ \\
\hline Total & 101.5 & 155.4 & 122.1 & $126.4(46.1)$ \\
\hline \multicolumn{5}{|l|}{ Large copepods } \\
\hline Calanus chilensis & 11.3 & 49.2 & 165.7 & $75.4(80.5)$ \\
\hline Eucalanus sp. & 401.4 & 51.4 & 69.9 & $174.2(197)$ \\
\hline Candacia sp. & 10 & 1.6 & 12.6 & $8.1(5.7)$ \\
\hline Metridia longa & 2.8 & 0 & 0 & $0.9(1.6)$ \\
\hline Total & 425.6 & 102.2 & 248.2 & $258.6(284.8)$ \\
\hline Appendicularians & 6.4 & 0.3 & 2.4 & $3.1(3.1)$ \\
\hline \multicolumn{5}{|l|}{ Euphausiids } \\
\hline Adults & 0 & 0 & 0 & $0(0)$ \\
\hline Juvenile & 0 & 0 & 0 & $0(0)$ \\
\hline Calyptopis & 19.2 & 0 & 1.7 & 7 (10.6) \\
\hline Furcilia & 0 & 0 & 56.5 & $18.8(32.6)$ \\
\hline Total & 19.2 & 0 & 58.1 & $25.8(43.2)$ \\
\hline
\end{tabular}




\section{Quantitative significance of microheterotrophs in a coastal upwelling area}

The abundance and biomass of different protozoan groups have not been previously described for upwelling areas along the Humboldt Current System. Our estimates of protozooplankton carbon biomass are consistent with values in the literature. In the upper $25 \mathrm{~m}$ depth layer, the biomass of $\mathrm{h}$-dinoflagellates ranged between 1 and $6 \mathrm{mg} \mathrm{C} \mathrm{m}^{-3}$ (i.e. 23 to $144 \mathrm{mg} \mathrm{C}$ $\mathrm{m}^{-2}$ ) inside Mejillones Bay, with a peak of $66 \mathrm{mgC} \mathrm{m}^{-3}$ at Stn 2 during February. The biomasses of h-dinoflagellates generally range between 0.1 and $50 \mathrm{mgC} \mathrm{m}^{-3}$ (Lessard 1991). For comparison, in the Benguela upwelling system, dinoflagellate biomass ranged between 7 and $16 \mathrm{mg} \mathrm{C} \mathrm{m}^{-3}$ in Elands Bay (Pitcher 1986) and from 5 to $49 \mathrm{mgC} \mathrm{m}^{-3}$ in St Helena Bay (Pitcher 1988). Conversely, the contribution of ciliates to carbon biomass was low during our study, ranging between 0.6 and $3 \mathrm{mgC} \mathrm{m}^{-3}$ (15 to $77 \mathrm{mgC} \mathrm{m}^{-2}$ ) inside Mejillones Bay (upper $25 \mathrm{~m}$ ). In general, ciliate biomass is relatively low in upwelling areas. In the Benguela system, Painting et al. (1992) reported a mean biomass of around $7 \mathrm{mgC} \mathrm{m}^{-3}$. Ciliates and h-dinoflagellates biomass also compares well with that in the Oregon upwelling system, which ranged from 0.2 to $9 \mathrm{mgC} \mathrm{m}^{-3}$ for choreotrich ciliates and from 0.1 to $16 \mathrm{mg} \mathrm{C} \mathrm{m}^{-3}$ for thecate dinoflagellates (Neuer \& Cowles 1994). Sorokin (1978) found protozoan biomass (ciliates and flagellates) to be between 20 and $50 \mathrm{mgC} \mathrm{m}^{-3}$ in surface waters of the Peruvian upwelling region. These values are also well within the range found for total protozoan biomass in our study (10 to $150 \mathrm{mg} \mathrm{C} \mathrm{m}^{-3}$ ).

Earlier studies by Goldman \& Caron (1985), Parslow et al. (1986) and Sherr et al. (1986) indicated that many microprotozoan organisms cannot be allocated into exclusively autotrophic, heterotrophic or bacterivorous compartments. We attempted to estimate predatorprey interactions, taking into account the main trophic interactions reported in the literature. Potential ingestion rates estimated using Peters' (1994) model were in the range of those reported in different studies in coastal and oceanic areas. Fenchel (1982) demonstrated that flagellates could be major consumers of bacteria, and described them as the main grazers in the pelagic ecosystem. Since ingestion rates reported in the literature for marine and freshwater systems typically range between 10 and 75 bacteria h-nanoflagellate $^{-1} \mathrm{~h}^{-1}$ (e.g. Fenchel 1982, Andersen \& Fenchel 1985, Sherr et al. 1988, Boenigk et al. 2001), we believe that our values are a realistic approximation for grazing on bacteria. In fact, in the upwelling area off Central Chile $\left(36^{\circ} \mathrm{S}\right)$, Cuevas (1999) observed a mean ingestion rate for h-nanoflagellates (h-nano) of $\sim 54$ bacteria hnano $^{-1} \mathrm{~h}^{-1}$.
Trophic relationships between ciliates and phytoplankton are more unusual, since previous studies have shown that naked oligotrich and choerotrich ciliates feed almost exclusively on nanoplankton (Rassoulzadegan et al. 1988, Bernard \& Rassoulzadegan 1990). The estimated ingestion rates in our study were similar to those reported in the literature (Verity 1985, Sherr et al. 1988, Šimek et al. 1996, Christaki et al. 1999, Tang et al. 2001). Occasionally, small aloricate ciliates may consume bacteria at rates similar to flagellates, and display a greater preference for larger bacteria than flagellates (Epstein \& Shiaris 1992). In our study, estimated ciliate ingestion rates were $\sim 270$ to 660 bacteria ciliate ${ }^{-1} \mathrm{~h}^{-1}$, which fit very well with results reported in the literature for small aloricate ciliates (Table 2). In experiments with fluorescent labeled bacteria, Sherr et al. (1988) reported high ingestion rates of ciliates on bacteria, whereby Uronema marina ingested $\sim 710$ bacteria ciliate ${ }^{-1} \mathrm{~h}^{-1}$ and Strombidium sulcatum ingested 1095 bacteria ciliate $^{-1}$ $\mathrm{h}^{-1}$ at 22 and $19.5^{\circ} \mathrm{C}$ respectively.

Marine heterotrophic thecate dinoflagellates feed with a pseudopod or 'pallium'. This structure is highly plastic, and easily stretches to accommodate spines and most large diatoms chains (Gaines \& Taylor 1984, Jacobson \& Anderson 1986). In our study, we considered only trophic interactions between h-dinoflagellates and diatoms, a decision based on the fact that Protoperidinium was the most abundant h-dinoflagellates generus during our study: with few exceptions, Protoperidinium species have been observed to feed only on diatoms (Jacobson \& Anderson 1986), and small flagellates are generally not able to support Protoperidinium spp. growth (Naustvoll 2000). Although h-dinoflagellates were not a dominant constituent of biomass, they were important herbivores with important impacts on carbon fluxes.

\section{Planktonic production and carbon flow}

Carbon flux in the ocean depends mainly on the magnitude of primary production and the biogeochemical processes within the euphotic zone, as well as on the complexity of the pelagic food web. Since the photic layer during our study ranged between 20 and $25 \mathrm{~m}$ depth, biomass, production and ingestion rate measurements were integrated between 0 and $25 \mathrm{~m}$ to construct a carbon budget for each sampling period (Figs. 5, 6 \& 7). Although the hydrography of the sampling area is highly dynamic, and advection could greatly influence our results, the southern boundary of Mejillones Bay (Stn 1: Fig. 1) has been characterized as a region of reduced upwelling (i.e. of 'upwelling shadow' sensu Graham \& Largier 1997), where oceanographic conditions generate an internal eddy and more stable conditions than outside 


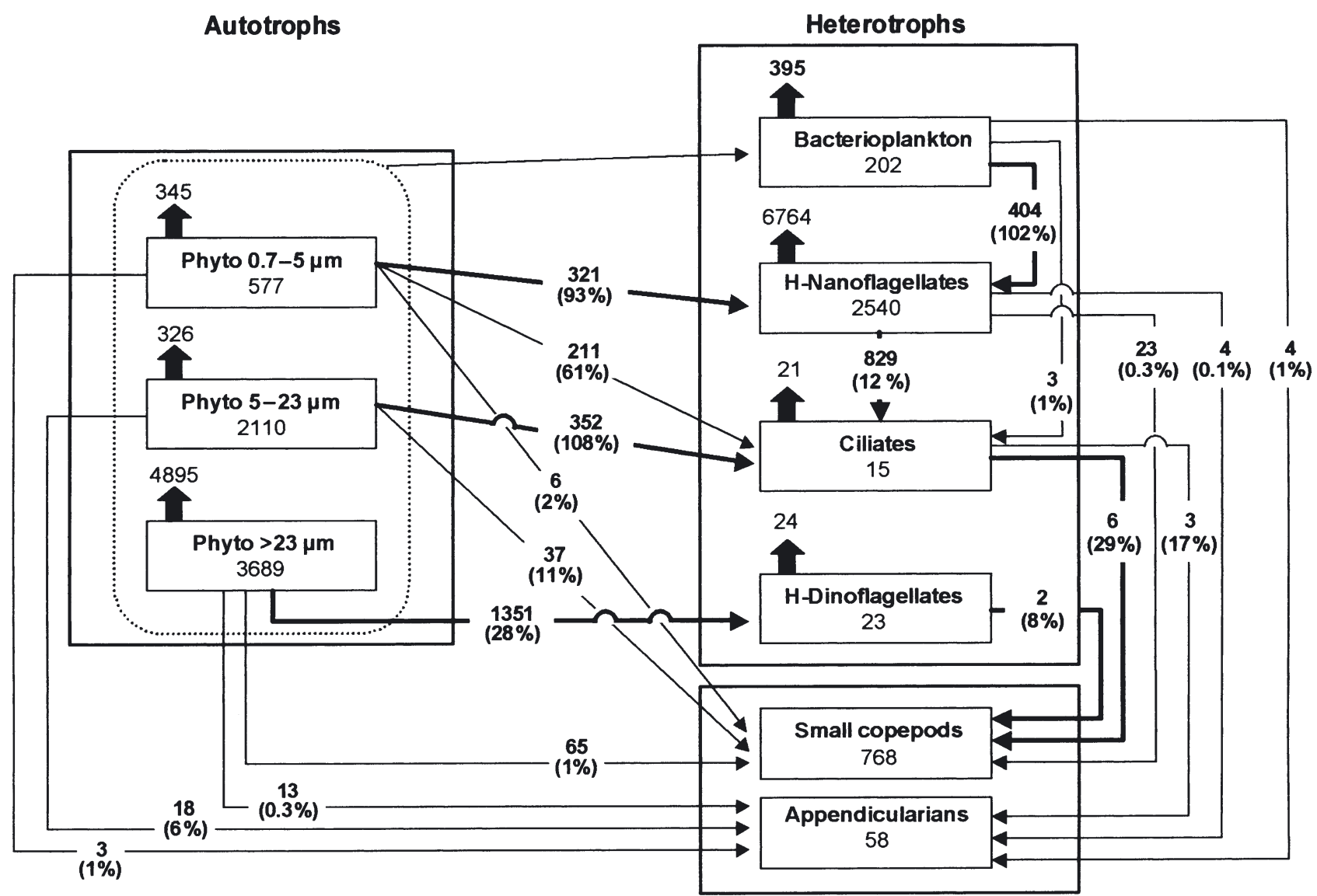

Fig. 5. Carbon budget in February 2001. Nos. inside boxes: biomass $\left(\mathrm{mg} \mathrm{C} \mathrm{m}^{-2}\right)$; nos. above black arrows: production $\left(\mathrm{mg} \mathrm{C} \mathrm{m}^{-2} \mathrm{~d}^{-1}\right)$; nos. on thin continuous arrows: consumption $\left(\mathrm{mg} \mathrm{C} \mathrm{m}^{-2} \mathrm{~d}^{-1}\right)$. Values in parantheses: \% of production ingested. Biomass, production and consumption values integrated between 0 and $25 \mathrm{~m}$ depths. Continuous lines represent main fluxes between boxes

the bay (Marín et al. 2001). Therefore, a carbon budget was constructed for Stn 1, inside Mejillones Bay, where J. Iriarte \& H. González (unpubl.) also measured sizefractioned PP. During our study, we did not measured bacterial production (BP). However, in a coastal station close to Mejillones Bay, Iriarte et al. (2000) measured BP during the summer, recording values of $\sim 15.8 \mu \mathrm{gCl}^{-1} \mathrm{~d}^{-1}$ which, integrated over the upper $25 \mathrm{~m}$ depth layer, would be $\sim 395 \mathrm{mgC} \mathrm{m}^{-2} \mathrm{~d}^{-1}$ (except during October when extremely low bacterial biomass was recorded). We considered that our results could have been substantially influenced by PP variability, since BP is closely related to PP (Kirchman et al. 1995). BP was assumed to derive primarily from photosynthetically produced dissolved organic carbon (DOC) and 'sloppy feeding' of zooplankton, and to represent only $\sim 8 \%$ of total PP (Figs. $5 \& 6$ ). This is supported by the fact that Mejillones Bay lacks a freshwater contribution from rivers, and is a highly productive system (Rodríguez et al. 1991, Marín \& Olivares 1999). In addition, the diatom species found during our study typically showed the highest percent- age of extracellular release of DOC (e.g. Chaetoceros spp.: Nagata 2000).

Calculation of grazing pressure showed that $h$ nanoflagellates were capable of removing a high percentage of BP during February and August (102 and $55 \% \mathrm{BP} \mathrm{d}^{-1}$, respectively; Figs. 5 \& 6). H-nanoflagellates were also able to daily remove between 69 and $93 \%$ of PP from small cells $(0.7$ to $5 \mu \mathrm{m})$, and had the highest impact on this fraction. The grazing impact of ciliates on small autotrophs was important, particularly in February, when ciliates removed $108 \% \mathrm{~d}^{-1}$ of ananoflagellates PP (5 to $23 \mu \mathrm{m}$; Fig. 5). Ciliates were also the most important grazers of h-nanoflagellates, and were possibly able to remove between 12 and $22 \%$ of the daily h-nanoflagellate production. Since only small aloricate ciliates (ca. 25 to $30 \%$ of total ciliates in this study) can exploit bacteria (Sherr et al. 1989), an insignificant percentage of the BP (0.2 to $2 \%$ $\mathrm{d}^{-1}$ ) was ingested by total ciliates. These results are in agreement with those of other studies, which have shown that ciliates strongly influenced the nanoflagel- 


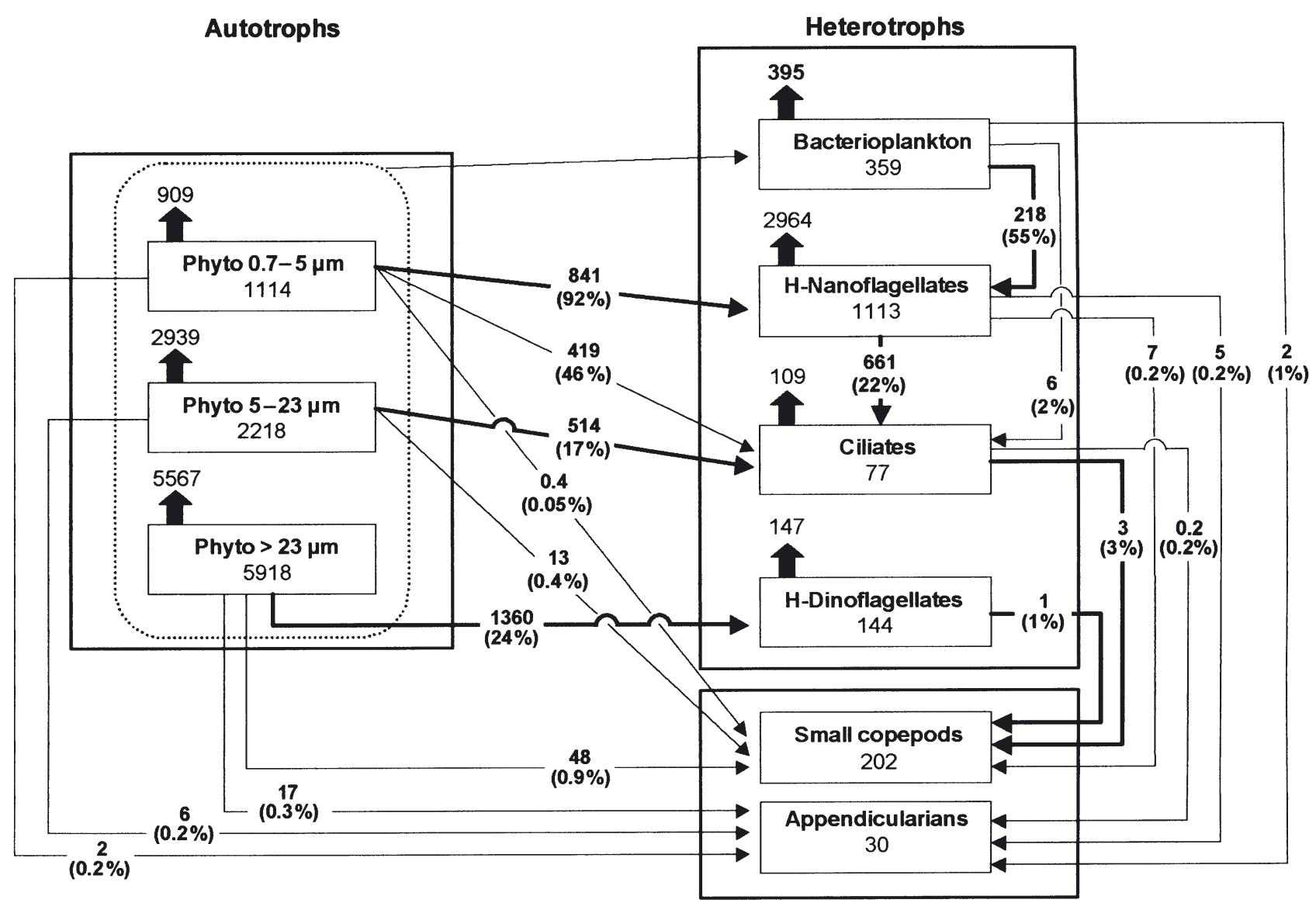

Fig. 6. Carbon budget in August 2001. Further details as in legend to Fig. 5

late community, even when present in low abundance (Epstein \& Shiaris 1992).

Despite their low abundance in this coastal upelling system, h-dinoflagellates had a major predation impact on large cells $(>23 \mu \mathrm{m})$, since they may remove between 18 and $28 \%$ of PP of this fraction. The estimates of grazing impact on diatom biomass and production illustrate that h-dinoflagellates play an important role in controlling the autotrophic production of cells $>23 \mu \mathrm{m}$. Thus, ciliates may compete with h-nanoflagellates for bacteria and small flagellates $<5 \mu \mathrm{m}$, while the larger h-dinoflagellates may compete with copepods for large diatoms (Nielsen \& Hansen 1995). The impact of small zooplankton on PP was relatively low during the whole sampling period. Small copepods removed between 0.6 and $5 \% \mathrm{PP} \mathrm{d}^{-1}$, with the highest impact in October when PP was relatively low. Appendicularians (mostly Oikopleura dioica) removed 0.08 to $0.6 \% \mathrm{PP} \mathrm{d}^{-1}$, and both copepods and appendicularians had a major grazing impact on the nanoplankton fraction. However, the impact of appendicularians could have been more significant offshore (Stn 3) in August, when they constituted $12 \%$ of zooplankton biomass (Table 4 ).
González et al. (1998) constructed a conceptual model of carbon flow from estimated PP. In the coastal area off Peninsula Mejillones, approximately $12 \%$ of the total PP was consumed by mesozooplankton. However, it should be noted that in the study by González et al. (1998), total average PP ranged between 2 and $3 \mathrm{~g} \mathrm{C}$ $\mathrm{m}^{-2} \mathrm{~d}^{-1}$, a much lower range than the 1 to $9 \mathrm{~g} \mathrm{C} \mathrm{m}^{-2} \mathrm{~d}^{-1}$ $\mathrm{PP}$ recorded during the present study in February and August by J. Iriarte \& H. González (unpubl.). In fact, population grazing-impact in the present study was similar to that recorded by González et al. $(1998,2000)$. The population grazing impact measured by González et al. $(1998,2000)$ was around 250 to $300 \mathrm{mg} \mathrm{C} \mathrm{m}^{-2} \mathrm{~d}^{-1}$, while during our study it was between 60 and $150 \mathrm{mg} \mathrm{C}$ $\mathrm{m}^{-2} \mathrm{~d}^{-1}$. However, we did not consider grazing by large copepods (Calanus chilensis and Eucalanus sp.). Our biomass data showed that large copepods were not abundant, and salps were not found in Mejillones Bay; therefore, most grazing in our study was by small copepods and appendicularians, and large copepods could have removed only a small percentage of the PP in the $>23 \mu \mathrm{m}$ fraction. Abundance of both small cyclopoids and appendicularians may also have been somewhat 


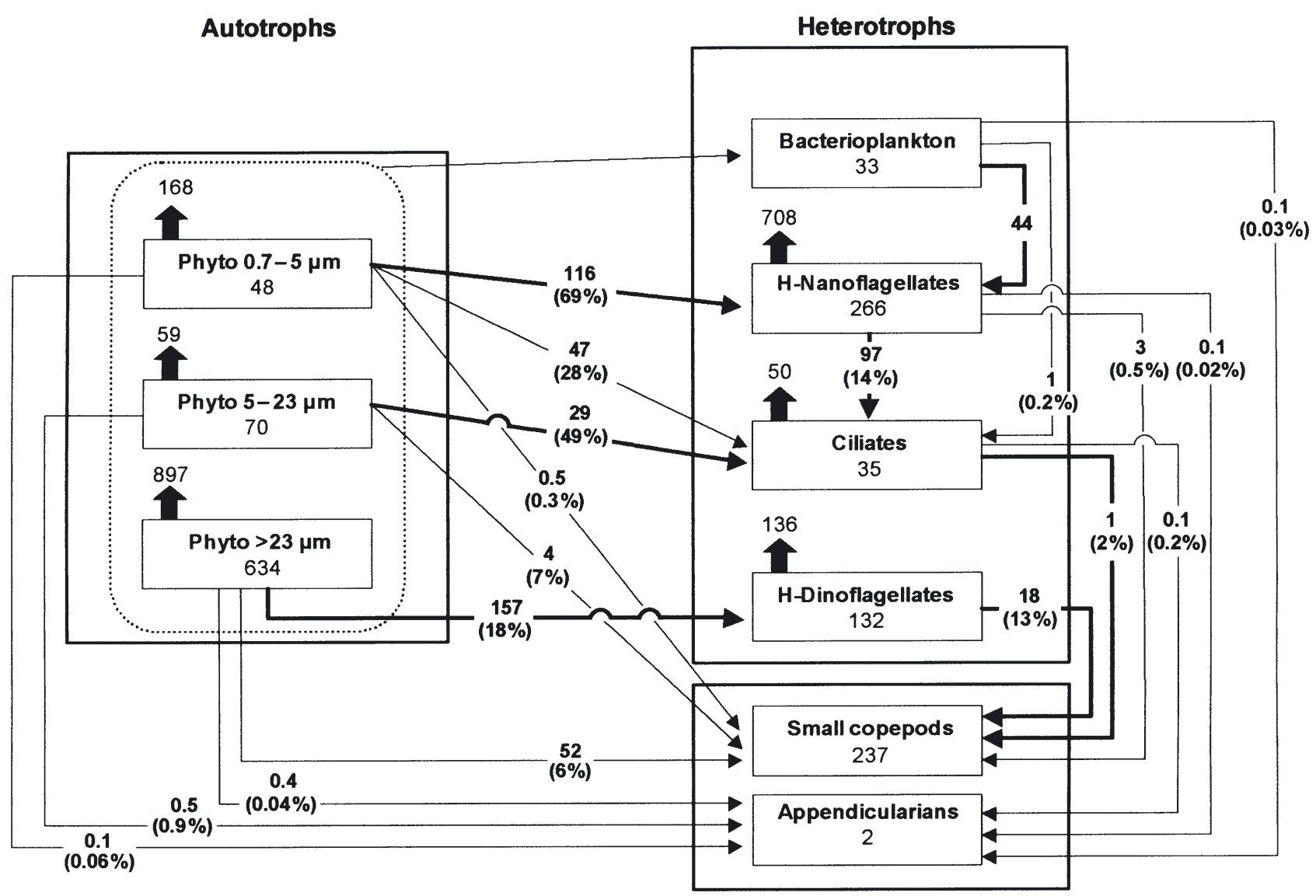

Fig. 7. Carbon budget in October 2001. Further details as in legend to Fig. 5

underestimated during our study, which used a $200 \mu \mathrm{m}$ net (Krsinic \& Lucic 1994, Gallienne \& Robins 2001). However, since Oikopleura dioica individuals in our samples ranged between 0.8 to $1.2 \mathrm{~mm}$ in size, we assume that only the early developmental stages of $O$. dioica could have been undersampled. Appendicularians were the only zooplankton group able to graze on bacteria at $\sim 1 \% \mathrm{BP} \mathrm{d}^{-1}$, a rate which is not sufficient to have any effect on bacterial biomass but important enough to transfer a significant amount of bacterial carbon directly to higher trophic levels (e.g. fish larvae) (King et al. 1980, Gorsky \& Fenaux 1998). Small copepods showed a strong top-down control of ciliates and dinoflagellates, which transferred nanoplanktonic carbon towards higher trophic levels. In February, small copepods removed $29 \%$ of the ciliate production, and during October, when PP was low, small copepods fed on h-dinoflagellates, consuming $13 \%$ of their production (Figs. $5 \& 7$ ). Thus, high clearance rates of copepods on h-dinoflagellates may also result in a significant impact on these protozoans, which are important competitors for diatoms. Because of the extremely high PP in this coastal embayment, a potential high produc- tion of DOC could support bacterial production, which is efficiently utilized by h-nanoflagellates and ciliates and subsequently by copepods and appendicularians, fuelling the microbial carbon pathways (Uitto et al. 1997). Even though appendicularians may extend the size range of plankton grazed upon, the grazing exerted by both small copepods and appendicularians was not high enough to control the phytoplankton blooms generated during upwelling events. Accordingly, a high percentage of PP would be available for other metabolic processes in the water column (e.g. respiration), for offshore exportation or for sedimentation. Measurements of $\mathrm{pCO}_{2}$ in the ocean-atmosphere interphase and vertical carbon fluxes during El Niño 1997/1998 by González et al. (1998) showed that carbon sequestration in Mejillones Bay accounted for only a small fraction of PP ( 3 to $8 \% \mathrm{PP} \mathrm{d}^{-1}$ ), suggesting that recycling is important in this bay. Comparison with other biological carbon fluxes measured in a parallel study by Eissler \& Quiñones (1999) suggests that microplankton respiration comprises the highest non-phototrophic carbon flux, and consequently is a crucial factor for the flux of carbon to the deep ocean. 
Our results show that microprotozoans can remove a significant percentage of PP (26 to $45 \% \mathrm{~d}^{-1}$ ), and have a much higher impact than small zooplankton (1 to $6 \% \mathrm{~d}^{-1}$ ). Our estimates of microprotozoan impacts are within the range found in coastal waters off Washington, USA (17 to 52\%: Landry \& Hassett 1982), the Baltic Sea (23\%: Uitto et al. 1997); and Gulf of St Lawrence (40 to $100 \%$ : Tamigneaux et al. 1997). Therefore, the microheterotrophic pathway may also be an important link in highly productive upwelling areas. The present study is one of the first to provide data that clearly show that the microbial-loop pathway is an important link in carbon fluxes of coastal upwelling ecosystems. In this type of ecosystem, some of the carbon from bacterial and protozoan production may pass to larger zooplankton, and subsequently to large metazoans (e.g. fish larvae). According to the classification of trophic pathways by Legendre \& Rassoulzadegan (1995), the food-web structure found during our study would be classified as multivorous, whereby herbivorous and microbial grazing modes both have significant roles in carbon export. Nevertheless, the concept of carbon export in a highly dynamic upwelling area is very complex; in addition to enter trophic pathways, autotrophic production may have several other pathways such as exportation to adjacent areas or burial in local sediments.

Acknowledgements. The assistance of the RV 'Purihaalar' crew is gratefully acknowledged. We thank L. Castro, S. Palma, P. Rosenberg, D. Fernandez, and P. Apablaza for help during fieldwork. We are also indebted to J. L. Iriarte for providing primary production data and to P. Santibañez for zooplankton abundance data. We are very grateful to T. G. Nielsen (National Environmental Research Institute, Denmark) and A. Sell (University of Hamburg) for constructive comments on an earlier version of the manuscript. C. Vargas was supported by the Escuela de Graduados, Universidad de Concepcion, CONICYT and MECESUP UCO-0002 doctoral fellowship during the preparation of the manuscript. The FONDECYT Project 1000419 to H. González supported this research. Additional support from FONDAP-COPAS Grant No. 150100007-2002 is acknowledged.

\section{LITERATURE CITED}

Andersen P, Fenchel T (1985) Bacterivory by microheterotrophic flagellates in seawater samples. Limnol Oceanogr 30:198-202

Aravena G, Palma S (2002) Taxonomic identification of appendicularians collected in the epipelagic waters off northern Chile (Tunicata, Appendicularia). Rev Chil Hist Nat 75:307-323

Beers JR, Stevenson MR, Eppley RW, Brooks EL (1971) Plankton populations and upwelling off the coast of Peru, June 1969. Fish Bull Fish Wildl Serv US 69:859-876

Bernard C, Rassoulzadegan F (1990) Bacteria or microflagellates as a major food source for marine ciliates: possible implications for the microzooplankton. Mar Ecol Prog Ser 64:147-155
Boenigk J, Matz C, Jürgens K, Arndt H (2001) The influence of preculture conditions and food quality on the ingestion and digestion process of three species of heterotrophic nanoflagellates. Microb Ecol 42:168-176

Boudreau PR, Dickie LM (1992) Biomass spectra of aquatic ecosystems in relation to fisheries yield. Can J Fish Aquat Sci 49:1528-1538

Christaki U, Jacquet S, Dolan JR, Vaulot D, Rassoulzadegan F (1999) Growth and grazing on Prochlorococcus and Synechococcus by two marine ciliates. Limnol Oceanogr 44: $52-61$

Cuevas A (1999) Interacción entre el bacterioplancton y nanoflagelados heterótrofos en la zona central de Chile (Pta. Nugurué-Pta. Lavapié). Marine Biology Theses, Departamento de Oceanografía, Universidad de Concepcion

Cury PA, Bakun A, Crawford RJM, Jarre A, Quiñones RA, Shannon LJ, Verheye HM (2000) Small pelagics in upwelling systems: patterns of interaction and structural changes in 'wasp-waist' ecosystems. ICES J Mar Sci 57: 603-618

Dagg MJ, Green EP, McKee BA, Ortner PB (1996) Biological removal of fine-grained lithogenic particles from a large river plume. J Mar Res 54:149-160

Daneri G, Dellarossa V, Quiñones R, Jacob B, Montero P, Ulloa O (2000) Primary production and community respiration in the Humboldt Current System off Chile and associated oceanic areas. Mar Ecol Prog Ser 197:41-49

Davis PG, Sieburth JMcN (1982) Differentiation of phototrophic and heterotrophic nanoplankton populations in marine waters by epifluorescence microscopy. Ann Inst Océanogr 58 (Suppl):249-260

Ducklow HW, Smith DC, Campbell L, Landry MR, Quinby HL, Steward GF, Azam F (2001) Heterotrophic bacterioplankton in the Arabian Sea: Basin wide response to yearround high primary productivity. Deep-Sea Res II 42: 1303-1323

Eissler Y, Quiñones R (1999) Microplanktonic respiration off northern Chile during El Niño 1997-1998. J Plankton Res 21:2263-2283

Epstein SS, Shiaris MP (1992) Size-selective grazing of coastal bacterioplankton by natural assemblages of pigmented flagellates, colorless flagellates, and ciliates. Microb Ecol 23:211-225

Escribano R (1998) Population dynamics of Calanus chilensis in the eastern Boundary Humboldt Current. Fish Oceanogr 7:245-251

Escribano R, Hidalgo P (2000) Spatial distribution of copepods in the north of the Humboldt Current region off Chile during coastal upwelling. J Mar Biol Assoc UK 80:283-290

Fenchel T (1982) Ecology of heterotrophic microflagellates. 4. Quantitative occurrence and importance as bacterial consumers. Mar Ecol Prog Ser 9:35-42

Gaines G, Taylor FJR (1984) Extracellular digestion in marine dinoflagellates. J Plankton Res 6:1057-1061

Gallienne CP, Robins DB (2001) Is Oithona the most important copepod in the world's oceans? J Plankton Res 23: 1421-1432

Goldman JC, Caron DA (1985) Experimental studies on an omnivorous microflagellate: implications for grazing and nutrient regeneration in the marine microbial food chain. Deep-Sea Res 32(8A):899-915

González HE, Daneri G, Figueroa D, Iriarte JL and 5 others (1998) Producción primaria y su destino en la trama trófica pelágica y océano profundo e intercambio océano-atmósfera de $\mathrm{CO}_{2}$ en la zona norte de la Corriente de Humboldt $\left(23^{\circ} \mathrm{S}\right)$ : posibles efectos del evento El Niño, 1997-98 en 
Chile. Rev Chil Hist Nat 71:429-458

González HE, Sobarzo M, Figureoa D, Nöthig EM (2000) Composition, biomass and potential grazing impact of the crustacean and pelagic tunicates in the northern Humboldt Current area off Chile: differences between El Niño and non-El Niño years. Mar Ecol Prog Ser 195:201-220

Gorsky G, Fenaux R (1998) The role of Appendicularia in marine food webs. In: Bone Q (ed) The biology of pelagic tunicates, Oxford University Press, Oxford, p 161-170

Gorsky G, Dallot S, Sardou J, Fenaux R, Carré C, Palazzoli I (1988) C and N composition of some northwestern Mediterranean zooplankton and micronekton species. J Exp Mar Biol Ecol 124:133-144

Graham W, Largier JL (1997) Upwelling shadows as nearshore retention sites: the example of northern Monterey Bay. Contin Shelf Res 17:509-532

Grünewald A, Quiñones R, Núñez S (1998) Spatial distribution and matter fluxes associated to appendicularians (Chordata, Tunicata) in central-south Chile. Gayana Oceanol 6 (1-2):11-23 (in Spanish)

Hansen PJ (1991) Quantitative importance and trophic role of heterotrophic dinoflagellates in a coastal pelagial food web. Mar Ecol Prog Ser 73:253-262

Hansen PJ, Bjørnsen PK, Hansen BW (1997) Zooplankton grazing and growth: scaling within the $2-2,000 \mu \mathrm{m}$ body size range. Limnol Oceanogr 42:687-704

Heinbockel JF (1978) Studies on the functional role of tintinnids in the Southern California Bight. II. Grazing rates of field populations. Mar Biol 47:191-197

Hirche HJ, Mumm N (1992) Distribution of dominant copepods in the Nansen Basin, Arctic Ocean, in summer. DeepSea Res 39A (Suppl): S485-S505

Hobbie JE, Daley RT, Jasper S (1977) Use of Nucleopore filters for counting bacteria by fluorescence microscopy. Appl Environ Microbiol 33:1225-1228

Iriarte JL, Pizarro G, Troncoso VA, Sobarzo M (2000) Primary production and biomass of size-fractioned phytoplankton off Antofagasta, Chile (23-24 $\left.{ }^{\circ} \mathrm{S}\right)$ during pre-El Niño and El Niño 1997. J Mar Syst 26:37-51

Jacobson DM, Anderson DM (1986) Thecate heterotrophic dinoflagellates: feeding behavior and mechanisms. J Phycol 22:249-258

Jeong HJ, Latz MI (1994) Growth and grazing rates of the heterotrophic dinoplagellates Protoperidium spp. on red tide dinoplagellates. Mar Ecol Prog Ser 106:173-185

King KR, Hollibaugh JT Azam F (1980) Predator-prey interactions between the larvacean Oikopleura dioica and bacterioplankton in enclosed water columns. Mar Biol 56: 49-57

Kirchman DL, Rich JH, Barber RT (1995) Biomass and biomass production of heterotrophic bacteria along $140^{\circ} \mathrm{W}$ in equatorial Pacific: effect of temperature on the microbial loop. Deep-Sea Res 42:603-619

Kivi K, Setälä O (1995) Simultaneous measurement of food particle selection and clearance rates of planktonic oligotrich ciliates (Ciliophora: Oligotrichina). Mar Ecol Prog Ser 119:125-137

Klein Breteler WCM, Fransz HG, González SR (1982) Growth and development of four calanoid copepod species under experimental and natural conditions. Neth J Sea Res 16: 195-207

Krsinic F, Lucic D (1994) Mesozooplankton sampling experiments with the 'Adriatic' sampler: differences of catch between 250 and $125 \mu \mathrm{m}$ mesh netting gauze. Estuar Coast Shelf Sci 38:113-118

Landry MR, Hassett RP (1982) Estimating the grazing impact of marine micro-zooplankton. Mar Biol 67:283-288
Landry MR, Lorenzen CJ (1989) Abundance, distribution and grazing impact of zooplankton on the Washington shelf. In: Landry MR, Hickey BM (eds) Coastal oceanography of Washington and Oregon. Elsevier, Amsterdam, p 175-210

Legendre L, Rassoulzadegan F (1995) Plankton and nutrient dynamics in marine waters. Ophelia 41:153-172

Lessard EJ (1991) The trophic role of heterotrophic dinoflagellates in diverse marine environments. Mar Microb Food Webs 5:49-58

Levinsen H, Nielsen TG, Hansen BW (1999) Plankton community structure and carbon cycling on the western coast of Greenland during the stratified summer situation. II. Heterotrophic dinoflagellates and ciliates. Aquat Microb Ecol 16:217-232

Li A, Stoecker DK, Wayne D (2001) Use of the food vacuole content method to estimate grazing by the mixotrophic dinoplagellate Gyrodinium galatheanum on cryptophytes. J Plankton Res 23:303-318

Mann KH (1992) Physical influences on biological processes: how important are they? In: Payne AIL, Brink KH, Mann $\mathrm{KH}$, Hilborn R (eds) Benguela trophic functioning. S Afr J Mar Sci 12:107-121

Marín VH, Olivares G (1999) Estacionalidad de la productividad primaria en Bahía Mejillones del Sur: una aproximación proceso-funcional. Rev Chil Hist Nat 72:629-641

Marín VH, Escribano R, Delgado LE, Olivares G, Hidalgo P (2001) Nearshore circulation in a coastal upwelling site off the Northern Humboldt current system. Contin Shelf Res 21:1317-1329

Morales C, Blanco J, Braun M, Reyes H, Silva N (1996) Chlorophyll-a distribution and associated oceanographic conditions in the upwelling region of northern Chile during the winter and spring 1993. Deep-Sea Res 43:267-289

Nagata T (2000) Production mechanisms of dissolved organic matter. In: Kirchman DL (ed) Microbial ecology of the oceans. Wiley-Liss, New York, p 121-152

Naustvoll LJ (2000) Prey size spectra and food preferences in thecate heterotrophic dinoflagellates. Phycologia 39: $187-198$

Navea E, Miranda O (1980) Ciclo anual de las condiciones oceanográficas en Mejillones del Sur (Chile). Rev Biol Mar 17:97-133

Neuer S, Cowles T (1994) Protist herbivory in the Oregon upwelling system. Mar Ecol Prog Ser 113:147-162

Newell RC, Turley CM (1987) Carbon and nitrogen flow through pelagic microheterotrophic communities. S Afr J Mar Sci 5:717-734

Nielsen TG, Hansen B (1995) Plankton community structure and carbon cycling on the western coast of Greenland during and after the sedimentation of a diatom bloom. Mar Ecol Prog Ser 125:239-257

Paffenhöfer GA (1976) On the biology of Appendicularia of the southern North Sea. In: Persoone G, Jaspers E (eds) Proc 10th Europ Symp Mar Biol. Universa Press, Wetteren, p 437-455

Painting SJ, Moloney CL, Probyn TA, Tibbles B (1992) Microheterotrophic pathways in the Southern Benguela upwelling system. In: Payne AIL, Brink KH, Mann KH, Hilborn R (eds) Benguela trophic functioning. S Afr J Mar Sci 12:527-543

Parslow JS, Doucette GJ, Taylor FJR, Harrison PJ (1986) Feeding by the zooflagellate Pseudobodo sp. on the picoplanktonic prasinomonad Micromonas pusilla. Mar Ecol Prog Ser 29:237-246

Peters F (1994) Prediction of planktonic protistan grazing rates. Limnol Oceanogr 39:195-206

Pitcher GC (1986) Sedimentary flux and the formation of rest- 
ing spores of selected Chaetoceros species at two sites in the southern Benguela system. S Afr J Mar Sci 4:231-244

Pitcher GC (1988) Mesoscale heterogeneities of the phytoplankton distribution in St Helena Bay, South Africa, following an upwelling event. S Afr J Mar Sci 7:9-23

Rassoulzadegan F, Laval-Peuto M, Sheldon RW (1988) Partitioning of the food ration of marine ciliates between pico and nanoplankton. Hydrobiologia 159:75-88

Rodriguez L, Marín V, Farías M, Oyarce E (1991) Identification of an upwelling zone by remote sensing and in situ measurements, Mejillones del Sur Bay (AntofagastaChile). Sci Mar 55:467-473

Riemann B, Bell RT (1990) Advances in estimating bacterial biomass and growth in aquatic systems Arch Hydrobiol 25:385-402

Ryther JH (1969) Photosynthesis and fish production in the sea. Science 166:72-76

Sherr BF, Sherr EB, Berman T (1983) Grazing, growth and ammonium excretion rates of a heterotrophic microflagellate fed with four species of bacteria. Appl Environ Microbiol 45:1196-1201

Sherr EB, Sherr BF, Fallon RD, Newell SY (1986) Small aloricate ciliates as a major component of the marine heterotrophic nanoplankton. Limnol Oceanogr 31:177-183

Sherr BF, Sherr EB, Rassoulzadegan F (1988) Rates of digestion of bacteria by marine phagotrophic protozoa: temperature dependence. Appl Environ Microbiol 54:1091-1095

Sherr EB, Rassoulzadegan F, Sherr BF (1989) Bacterivory by pelagic choreotrichous ciliates in coastal waters of the NW Mediterranean Sea. Mar Ecol Prog Ser 55:235-240

Šimek K, Macek M, Pernthaler J, Straškrabová, Psenner R (1996) Can freshwater planktonic ciliates survive on a diet of picoplankton? J Plankton Res 18:597-613

Simon M, Azam F (1989) Protein content and protein synthesis rates of planktonic marine bacteria. Mar Ecol Prog Ser 51:201-213

Smalley GW, Coats DW, Adam JE (1999) A new method using fluorescent microspheres to determine grazing on ciliates by the mixotrophic dinoflagellate Ceratium furca. Aquat Microb Ecol 17:167-179

Sobarzo M, Figueroa D (2001) The physical structure of a cold filament in a Chilean upwelling zone (Península de Mejillones, Chile, $\left.23^{\circ} \mathrm{S}\right)$. Deep-Sea Res 48:2699-2726

Sorokin YI (1978) Description of primary production and of the heterotrophic microplankton in the Peruvian upwelling region. Oceanology 18:62-71

Steeman Nielsen E (1952) The use of radiocarbon $\left({ }^{14} \mathrm{C}\right)$ for measuring organic production in the sea. J Cons Perm Int Explor Mer 18:117-140

Strickland JD, Parsons TR (1972) A practical handbook of seawater analysis, 2nd edn. Bull Fish Res Board Can 167

Editorial responsibility: John Dolan,

Villefranche-sur-Mer, France
Tamigneaux E, Mingelbier M, Klein B, Legendre L (1997) Grazing by protists and seasonal changes in the size structure of protozooplankton and phytoplankton in a temperate nearshore environment (western Gulf of St. Lawrence, Canada). Mar Ecol Prog Ser 146:231-247

Tang KW, Jakobsen HH, Visser AW (2001) Phaeocystis globosa (Prymnesiophyceae) and the planktonic food web: feeding, growth, and trophic interactions among grazers. Limnol Oceanogr 46:1860-1870

Tiselius P (1989) Contribution of aloricate ciliates to the diet of Acartia clausi and Centropages hamatus in coastal waters. Mar Ecol Prog Ser 56:49-56

Uitto A, Heiskanen AS, Lignell R, Autio R, Pajuniemi R (1997) Summer dynamics of the coastal planktonic food web in the northern Baltic Sea. Mar Ecol Prog Ser 151:27-41

Utermöhl H (1958) Zur Vervollkommung der quantitativen Phytoplankton-Methodik. Mitt Int Ver Theor Limnol 9: $1-38$

Uye SI (1982) Length-weight relationships of important zooplankton from the Inland Sea of Japan. J Oceanogr Soc Jpn 38:149-158

Vaqué D, Gasol JM, Marrasé C (1994) Grazing rates on bacteria: the significance of methodology and ecological factors. Mar Ecol Prog Ser 109:263-274

Vargas CA, González HE (2003) Plankton community structure and carbon cycling in a coastal upwelling system. I. Bacteria, microprotozoans and phytoplankton in the diet of copepods and appendicularians. Aquat Microb Ecol 34:151-164

Vargas CA, Tönnesson K, Sell A, Maar M and 8 others (2002) The importance of copepods versus appendicularians in vertical carbon fluxes in a Swedish fjord. Mar Ecol Prog Ser 241:125-138

Verity PG (1985) Grazing, respiration, excretion, and growth rates of tintinnids. Limnol Oceanogr 30:1268-1282

Verity PG, Sieracki ME (1993) Use of color image analysis and epifluorescence microscopy to measure plankton biomass. In: Kemp PF, Sherr BF, Sherr EB, Cole JJ (eds) Handbook of methods in aquatic microbial ecology. Lewis, London, p 327-338

Walker DR, Peterson WT (1991) Relationships between hydrography, phytoplankton production, biomass, cell size, and species composition, and copepod production in the southern Benguela upwelling system in April 1988. S Afr J Mar Sci 11:289-305

Walsh JJ, Row GT, Iverson RL, McRoy CP (1981) Biological export of shelf carbon is a sink of the global $\mathrm{CO}_{2}$ cycle. Nature 291:196-201

Zeldis J, James MR, Grieve J, Richards L (2002) Omnivory by copepods in the New Zealand subtropical frontal zone. J Plankton Res 24:9-23

Submitted: September 15, 2002; Accepted: September 15, 2003 Proofs received from author(s): January 27, 2004 